\title{
Benthic foraminiferal assemblages from the Safranbolu Formation (Cuisian, Eocene), Northwest Anatolia, Turkey
}

\author{
Kubra Okur ${ }^{*}$ and Hatice Kutluk
}

\begin{abstract}
Twenty-one outcrop samples collected from a 28-m-thick section from the Safranbolu Formation of the southwestern part of the Safranbolu Basin, Anatolia, Turkey yielded well-preserved benthic foraminifera belonging mainly to the genera Alveolina, Nummulites, Assilina, Rotalia, Disclocyclina and Orbitolites. Alveolina is the most diversified genus that is represented by sixteen species: Alveolina archiaci, A. axiampla, A. barattoloi, A. carantana, A. colatiensis, A. cuspidata, A. distefanoi, A. histrica, A. lehneri, A. oblonga, A. polatliensis, A. rakoveci gueroli, A. ruetimeyeri, A. rugosa, A. safranboluensis and A. sirelii. Alveolina safranboluensis and A. sirelii are described new. Comparison of the fossil assemblage with those assemblages previously reported from both Turkey and other Tethyan sub-basins revealed that the deposition occurred during the Cuisian (Eocene) and corresponded to Shallow Benthic Foraminiferal Zones (SBFZ) 10-12. The abundance and diversity of the larger benthic foraminifera indicated that the Safranbolu Formation was deposited under transgressive conditions.
\end{abstract}

Keywords: Eocene, Cuisian, Safranbolu Formation, Benthic foraminifera, Alveolina, Northwest Anatolia

\section{Introduction}

The temperature-sensitive, larger benthic foraminifera were among the most common microfossils in the Tethyan region and have been used successfully as index markers in establishing the marine stages of the late Paleocene-middle Eocene period. The shallow marginal areas of the subbasins circumscribing the Tethys Ocean which are composed mainly of carbonates and sometimes intercalated with terrigenous material, hosting rich and diverse assemblages of benthic foraminifera from the Atlantic Coast to the Indo-Pacific Ocean. The late Paleocene-middle Eocene period which is also known as the warmest period of all the Cenozoic Era with its rapid and pronounced temperature increases (e.g. Rea et al. 1990; Fricke and Wing 2004; Higgins and Schrag 2006; Lowenstein and Demicco 2006; Nicolo et al. 2007; Sexton et al. 2011; Foster et al. 2013) is a distinctive period in diversification and abundance of larger benthic foraminifera, belonging mainly to the genera Alveolina, Orbitolites, Nummulites and Assilina.

\footnotetext{
* Correspondence: kokur@ogu.edu.tr

Department of Geology, Eskişehir Osmangazi University, Bati Meselik, 26480 Eskişehir, Turkey
}

Benthic foraminiferal assemblages of the Thanetianearly Lutetian Safranbolu Formation were investigated in this study and compared with previously studied assemblages both in Turkey (Sirel 1976, 1992, 1998, 2000; Sirel and Gündüz 1976; Avşar 1992; Özgen 1998; İnan and İnan 1999; Özgen-Erdem 2002; Dinçer and Avşar 2004; Özgen-Erdem et al. 2005; Özcan et al. 2007; Sirel and Acar 2008; Özce et al. 2013) and in the Tethyan realm (Drobne et al. 2011; Molina et al. 2003; and references therein). Micropalaeontological investigations revealed that the Safranbolu Formation comprised a prolific assemblage of Alveolina species together with the genera Nummulites, Assilina, Discocyclina, Orbitolites and Rotalia. Alveolins, with their short stratigraphic range of the upper Paleocene-middle Eocene and wide geographical distribution around the entire Tethyan region, have been effectively used as index fossils in the assessment of palaeoenvironments and in solving biostratigraphical problems (Serra-Kiel et al. 1998; Sirel 1998; Dinçer and Avşar 2004; Özgen-Erdem et al. 2007; Sirel and Acar 2008; Drobne et al. 2011). The members of the genus were also important sediment contributors to shallowwater carbonate platforms (Sirel 1998; Sirel and Acar 
2008; Drobne et al. 2011). Their diversification at specific level, adaptation to a variety of ecological settings and occurrence in a wide range of habitats from deep lagoons to fore-reef settings make them a significant group of fossils of the Paleogene strata (Drobne et al. 2011). Alveolinids are among the most common microfossil group of larger benthic foraminera in Turkey too, and were reported from several carbonate-rich basins, such as Manisa, TavşanlıKütahya, Seyitgazi and Hanköy-Eskişehir, Orhaniye, Polath and Haymana-Ankara, Şarkışla-Sivas, Şarlakdere and Çamardı-Niğde, Karaman, Namrun-İçel, Darende-Malatya (Sirel 1976, 1998; Avșar 1992; Özgen 1998; İnan and İnan 1999; Dinçer and Avşar 2004; Özgen-Erdem et al. 2005, 2007; Sirel and Acar 2008; Özce et al. 2013). Drobne et al. (2011) in their study of the Paleogene Adriatic Platform, reviewed the spatial and stratigraphic distribution of alveolinids of the shallow zones of Tethyan margins from Spain, France, Italy, Greece, Turkey, Libya, Egypt, Somalia, Tanzania, Iran, Iraq, Lebanon, Palestine, Pakistan to the Persian Gulf. The aforementioned occurrences of alveolinids were inferred here for the comparisons of the taxa found in the Safranbolu Formation. The assemblage is expected to contribute to the understanding of the marine stages of the Tethyan region and elucidate palaeoenvironments of the early Eocene period.

\section{Geological setting}

The Safranbolu Basin (Fig. 1) is located in the western part of the North Anatolian Orogenic Belt, also referred to as the Pontides, which extends from the Rhodope Mountains in the Balkans in the West to the Caucasus in the East (Fig. 2; Görür and Tüysüz 2001). This belt is represented mainly by three units in Turkey: the Strandja Zone, the İstanbul Zone, and the Sakarya Continent (Fig. 2). All these three units display an affinity to belonging to the southern margin of the Laurasian Continent (Görür and Tüysüz 2001). The Safranbolu Basin was formed in the southeastern part of the İstanbul Zone (Fig. 2).

Palaeotectonic units that formed the landmass of modern Turkey were separated by the seaways of the Tethys Ocean during the Mesozoic (Yllmaz et al. 1997; Bozkurt and Mittwede 2001; Görür and Tüysüz 2001; Okay 2008; Moix et al. 2008). The commencement of the Alpide orogeny by the subduction of the Tethyan ocean floor beneath Laurasia resulted in progressive closure of the seaways between these units during the time span from the Late Triassic to the Eocene. The Pontides were the first tectonic unit that began to rise as a volcanic island-arc in an E-W direction as a result of the convergence of Gondwana towards Laurasia. While the Black Sea started to open as a marginal back-arc basin in the north, fore-arc basins were formed in the southern flanks. The formation of the magmatic arc and superimposed accretionary complexes consequently led to the development of arc-related sedimentary basins on an imbricated topography during the course of the subduction (Yllmaz et al. 1997; Görür and Tüysüz 2001; Okay 2008). The Safranbolu Basin is one of those arc-related basins in the southeastern part of the Western Pontides (Fig. 2). Besides the Safranbolu, several basins generated in this way along the southern flanks are now present in the suture zone (Saner 1980; Saner et al. 1980).

The geology of the Safranbolu Basin has a long history of study (e.g. Uysal 1959; Canik 1977; Saner 1980; Saner et al. 1980; Kaya and Dizer 1982; Sezen 1983; Öztürk et al. 1984; Keskin 2017). The Mesozoic units were unconformably overlain by the Safranbolu Formation (Saner 1980) (Fig. 3). The Safranbolu Formation in the northern part was underlain in part by the Ulus Formation and in the southern part by the Kışlaköy Formation, both of the Early Cretaceous age (Timur and Aksay 2002).

Flysch facies of turbiditic sandstone and shale of the Ulus and Kışlaköy Formations terminated with sandstone and conglomerate indicate the emergence of the Safranbolu Basin at the end of the Early Cretaceous (Saner et al. 1980; Koçyiğit 1987; Keskin 2017). A new depositional phase by the subsidence of the basin is inferred from calcareous sandstone after a long erosional period starting from the end of the Early Cretaceous until the early Paleocene (Thanetian). The early Paleocene calcareous sandstone was overlain by carbonates of the early Eocene age (Ilerdian), and laterally graded into argillaceous limestone of the Safranbolu Formation during the Cuisian with an influx of terrigenous material. The early Eocene (Ilerdian and Cuisian) sediments, therefore, can be ascribed as representing a shallow-marine shelf setting having fluvial influence. The deposition in the Safranbolu Formation completed with marls during the middle Eocene (Lutetian) which is conformably overlain by siltstone, sandstone and conglomerates of the Karabük Formation.

The Safranbolu Formation as a whole is characterised by a limestone-dominated lithology and is often called as 'Safranbolu Limestone' in the literature (Saner 1980). Limestone is of nodular type in the study area. A late Paleocene-middle Eocene age was assigned to the Safranbolu Formation based on stratigraphical relationships (Saner et al. 1980), and it was regarded as contemporaneous with the 'Evri Limestone', the 'Așllk Formation' of Kaya and Dizer (1982) and the 'Sazlar Formation' of Cerit (1983) of the neighbouring basins. Saner et al. (1980) pointed out the presence of reefal carbonates in limited areas of the east-west trending southern border of the Safranbolu Basin, presumably of fringe type since they were outcropped along the coastal borders of the basin.

Continued rise of the North Anatolian Mountains in the north, as a consequence of the $\mathrm{N}-\mathrm{S}$ compressional 


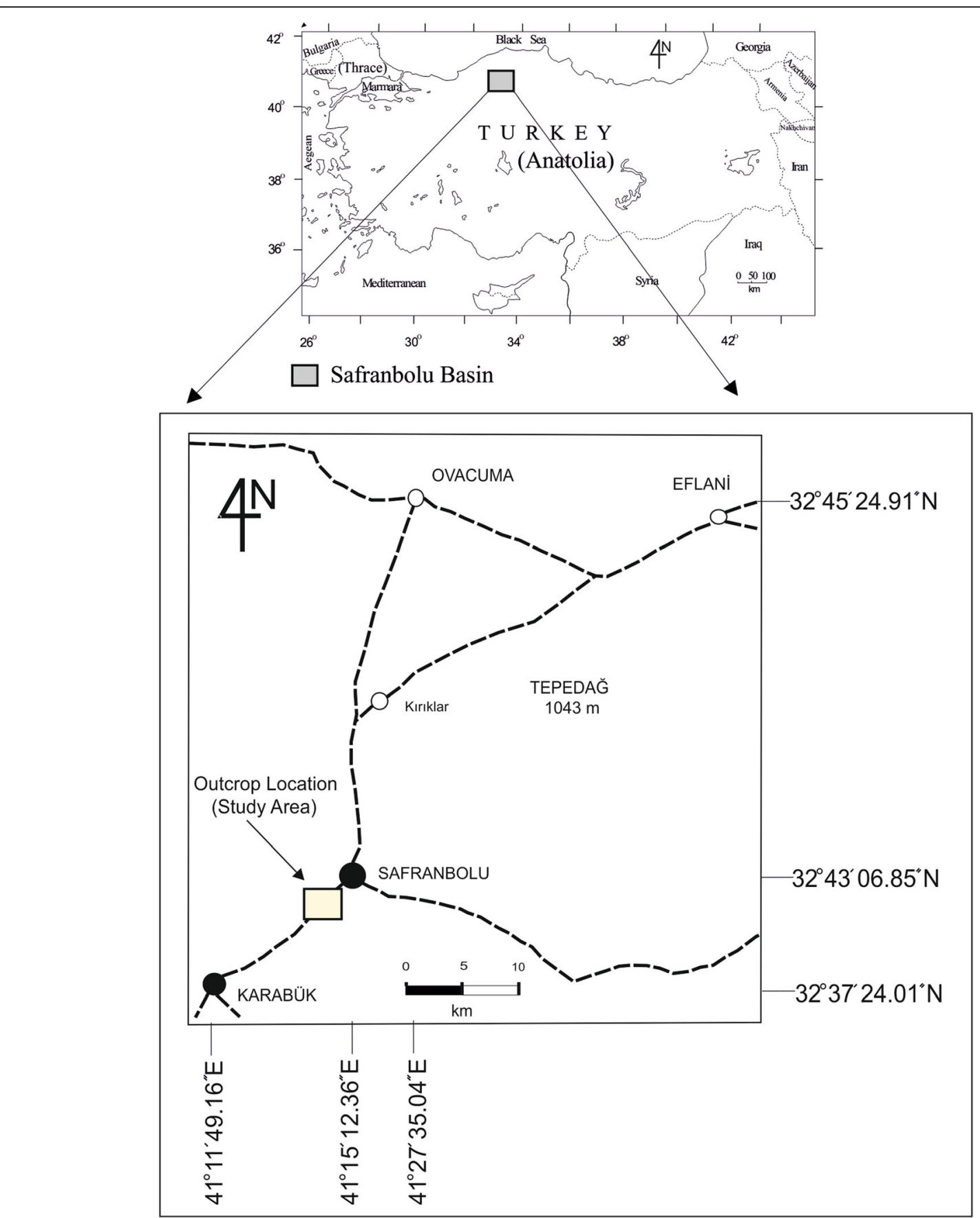

Fig. 1 Geographic map of the study area in the Safranbolu Basin, Turkey

forces that have been active in the region since the Late Triassic, formed an intermontane character of the Safranbolu Basin during the middle-late Eocene, and, led to the terminal closure of the basin during the late Eocene. The basin gained a molasse character with further filling of terrigenous sediments during the Oligocene and finally became an erosional area during the Neogene (Saner 1980; Saner et al. 1980; Timur and Aksay 2002). Besides, the N-S compressional forces resulted in the generation of a series of thrust faults in the region during the Eocene (Koçyiğit 1987).

\section{Material and method}

The Safranbolu Basin is a NE-SW trending funnel-shaped basin, with a width of $2-2.5 \mathrm{~km}$ in the west and $30-35 \mathrm{~km}$ in the east. The Early Cretaceous Ulus/Kışlaköy Formations and the early Eocene (Ilerdian) basal units of the Safranbolu Formation were not outcropped in the study 


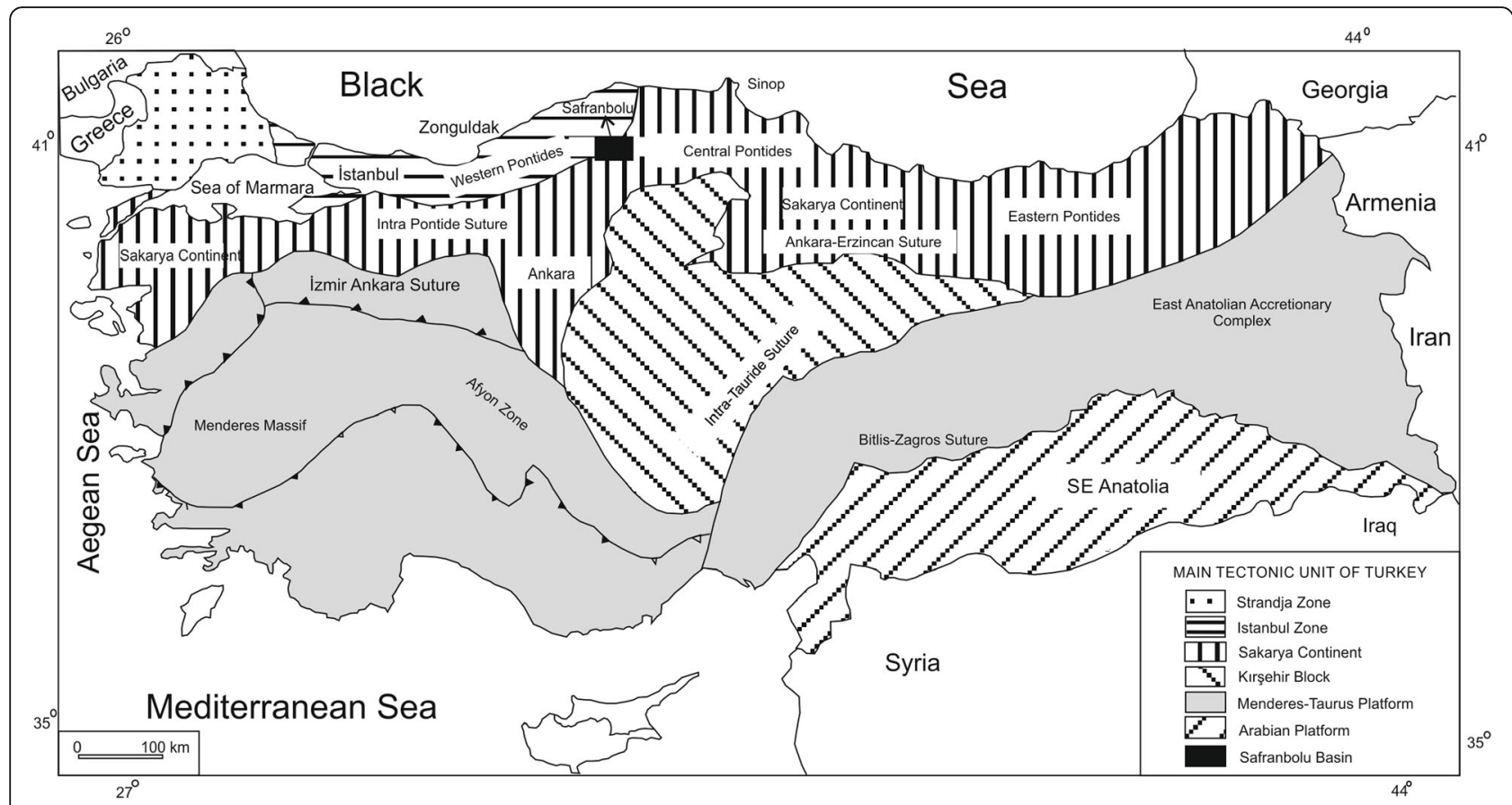

Fig. 2 Map showing major tectonic units of Turkey (after Görür and Tüysüz 2001)

area; and, the middle Eocene (Lutetian) marly layers of the Safranbolu Formation and the middle-late Eocene Karabük Formation were eroded away in the study area. The outcropped part of the Safranbolu Formation, however, has been observed in the southeastern sector of the study area across the valley during the field work, as shown in Fig. 4. The total thickness of the Safranbolu Formation attains up to $\sim 300 \mathrm{~m}$ (Özgen-Erdem et al. 2005), and the exposed segment of the formation in the study area displays $\sim 28 \mathrm{~m}$ thickness. Changes in thickness may be caused by the variations in palaeotopography on which the formation deposited.

The sampling was conducted in the section exposed at the southwestern sector (Fig. 4) of the Safranbolu Basin since the steep scarp of argillaceous limestone outcropped in the southeastern sector prevented the sampling, and were started from the upper part of 28-m-thick sequence. 21 outcrop samples were collected from three intervals, following fossiliferous levels, for this study (Figs. 4 and 5). Seven samples (Nos. 1-7) were collected from the first $9 \mathrm{~m}$ interval from the top, seven samples (Nos. 8-14) were from the next $8 \mathrm{~m}$ interval in the middle, and samples 15 21 were from the 11-m-thick bottom-interval of the total 28-m-thick section (Figs. 4 and 5). Seven among all these samples, mostly taken from the weathered and pulverized lithology, were barren of fossils (Table 1). Whole-rock hand-specimens from the rest 14 fossiliferous samples were prepared to obtain 250 oriented and random thin sections for the microscope study. Isolated grain specimens of some Alveolina, Nummulites, Orbitolites, Rotalia, and Assilina were also picked up for taxonomic analyses. Specimens were analysed under Carl Zeiss Axio Scope, Zeiss Imager M1 and Leica microscopes and were stored in the collection of Micropalaeontology laboratory of the Department of Geology, Eskişehir Osmangazi University.

Aforementioned occurrences of fossils both in Anatolia and other Tethyan sub-basins were inferred for determining the age and depostional environment of the Safranbolu Formation. The scheme of platform and pelagic marine zonation of Serra-Kiel et al. (1998) (Shallow Benthic Foraminiferal Zones, SBFZ) were utilised for the zonation. Alveolinid species encountered in the Safranbolu Formation, in Anatolia, and in the eastern, central and western Tethys are illustrated in Fig. 6; the stratigraphical range of alveolinid species is shown in Fig. 5 and Table 2; and, the spatial distribution of alveolinid species in the study area is illustrated in Fig. 7.

\section{Results and discussion}

\subsection{Systematic palaeontology}

Samples collected from the Safranbolu Basin yielded Alveolina archiaci, A. axiampla, A. barattoloi, A. carantana, A. colatiensis, A. cuspidata, A. distefanoi, A. histrica, A. lehneri, A. oblonga, A. polatliensis, A. rakoveci, A. ruetimeyeri, A. rugosa, A. safranboluensis, A. sirelii, A. aff. ruetimeyeri, A. cf. ruetimeyeri, $A$. cf. carantana, A. aff. Bronnimanni, $A$. aff. Cremea, together with the fossils of Nummulites partschi, Assilina spp., Discocyclina spp., Orbitolites spp., Rotalia spp., and Gastropoda. Alveolina safranboluensis and $A$. sirelii are herein newly described.

FORAMINIFERIDA Eichwald, 1830 


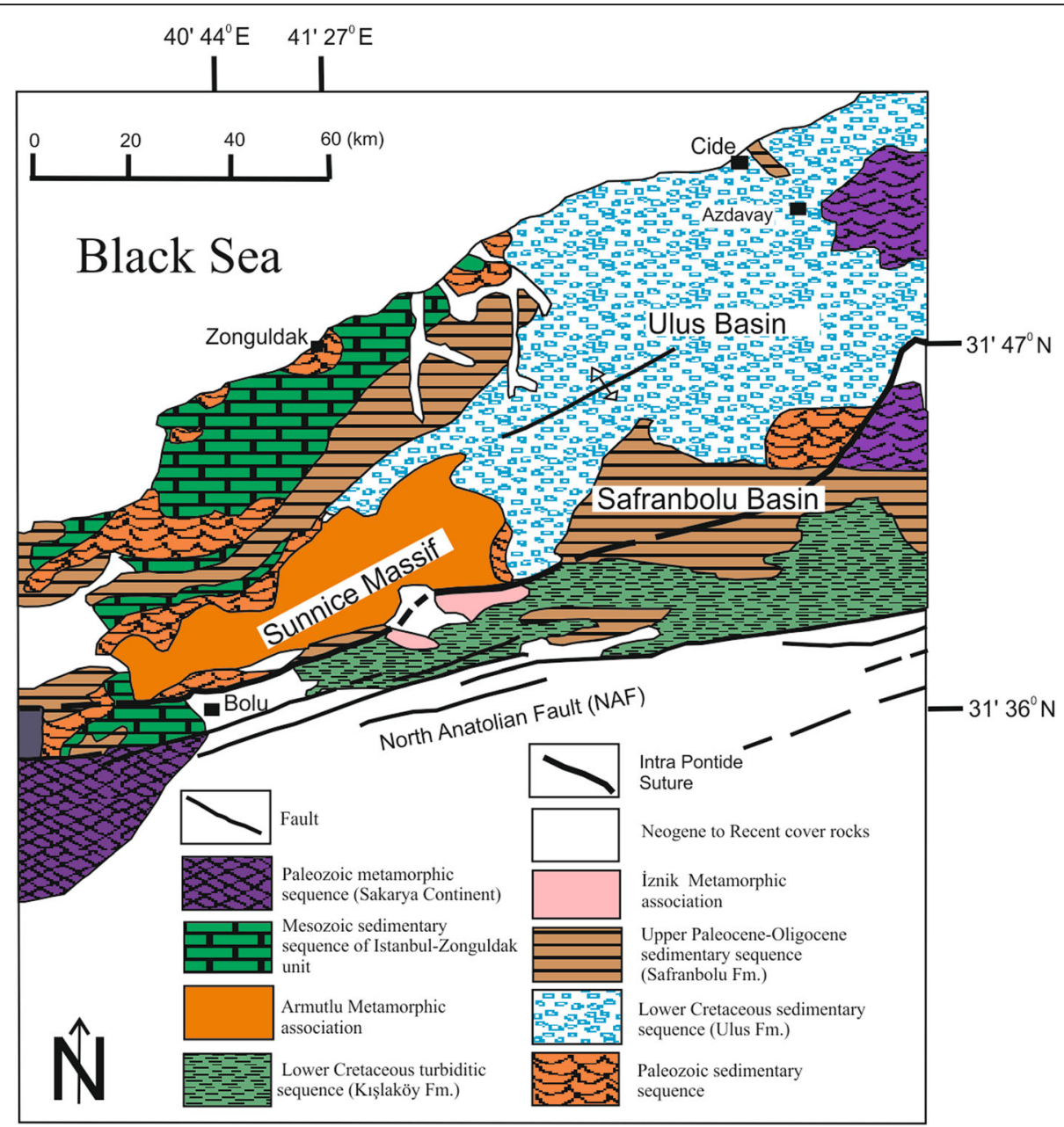

Fig. 3 Geological map of the study area, Turkey (modified after Yılmaz et al. 1997 and Timur and Aksay 2002)
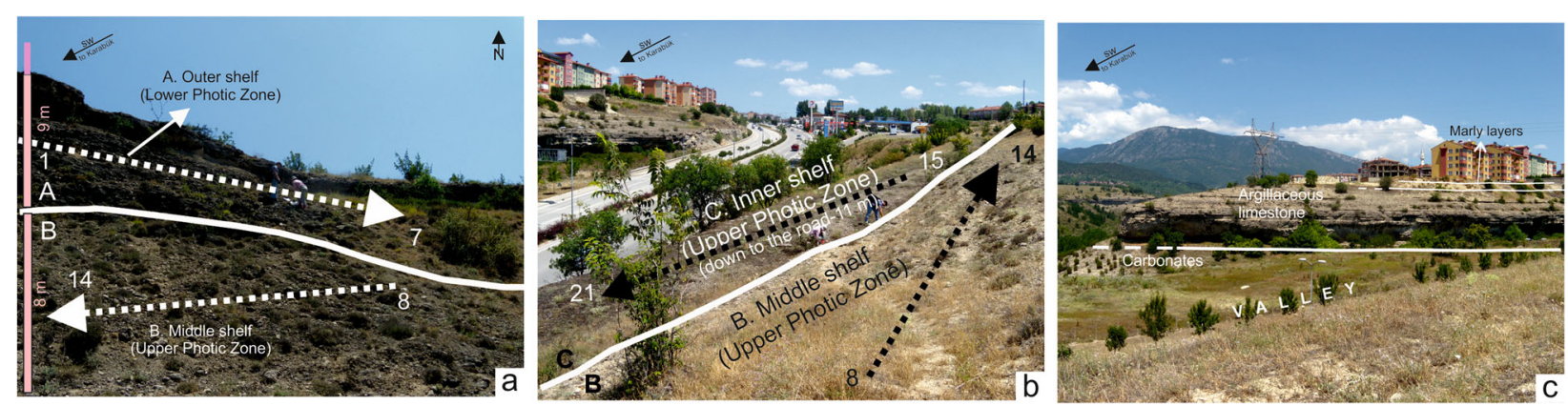

Fig. 4 Sample locations of the study area. a - Samples 1-7: Outer shelf (A) (Lower Photic Zone) and Samples 8-14: Middle shelf (B) (Upper Photic Zone); b - Samples 8-14: (Middle shelf (B) (Upper Photic Zone) and Samples 15-21: Inner shelf (C) (Upper Photic Zone); c - Counterpart of the study site showing complete sequence of argillaceous limestone across the eroded valley, underlain by carbonates and overlain by marly layers 


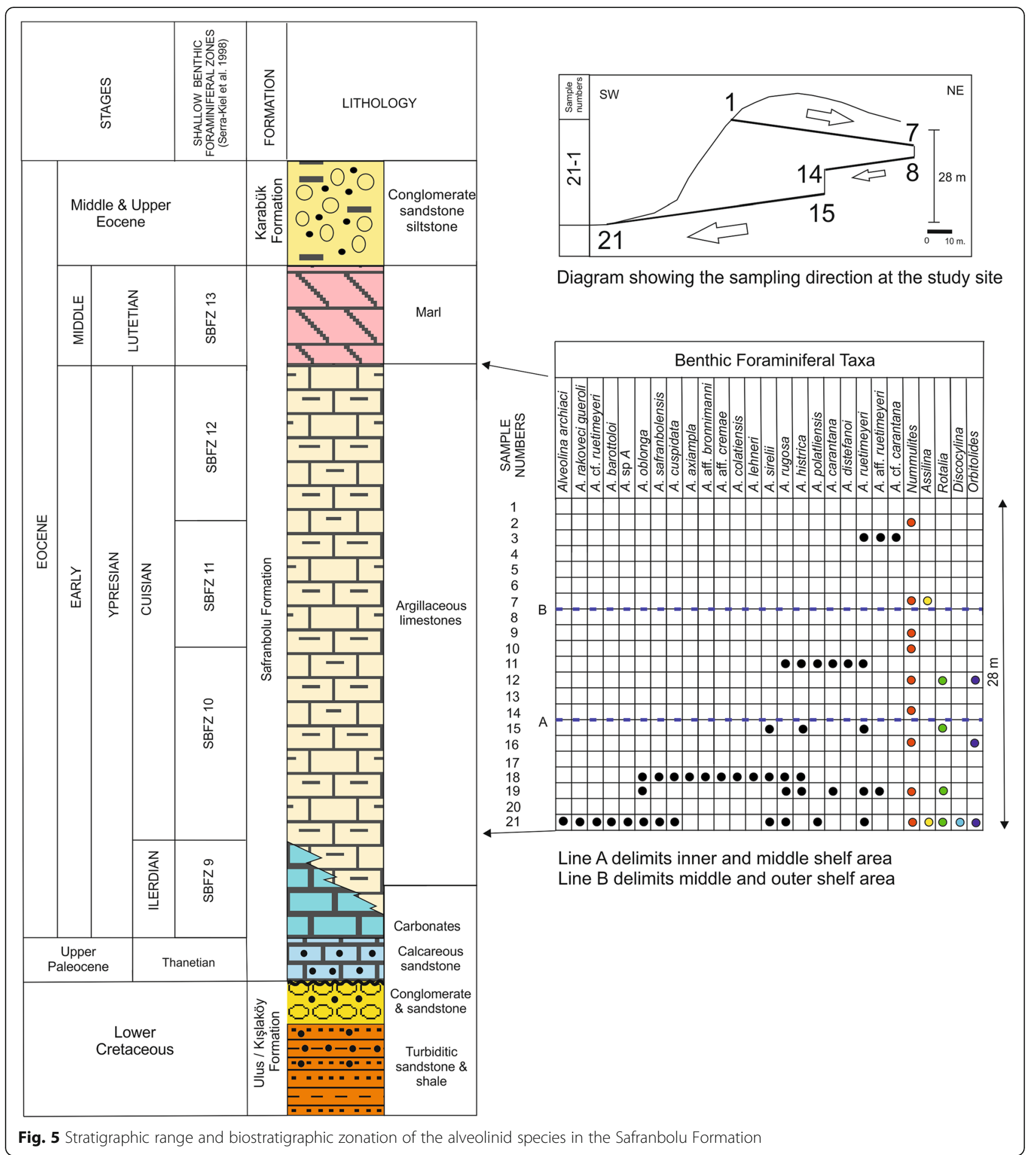

Superfamily ALVEOLINACEAE Ehrenberg, 1839 Family ALVEOLINIDAE Ehrenberg, 1839

Genus Alveolina D’Orbigny 1826

Alveolina archiaci Sirel and Acar 2008

Plate 1_1

(Slide No.: A2102; Sample No.: 21)
2008 Alveolina archiaci Sirel and Acar, p. 59, pl. 46, figs. 11-14.

Remarks: The test size of Alveolina archiaci is similar to $A$. barottoloi, however, $A$. archiaci differs from the latter by possessing a larger elongation index and smaller axial thickness hence containing more whorls. The only reported 
Table 1 Alveolinid species and the other benthic genera recorded in the Safranbolu Formation

\begin{tabular}{|c|c|c|}
\hline Environment & Sample Number & Fossil Record \\
\hline \multirow{7}{*}{$\begin{array}{l}\text { Deep (About 80-100 m) } \\
\text { Outer shelf (Lower photic zone) }\end{array}$} & 1 & Barren \\
\hline & 2 & Nummulites partschi \\
\hline & 3 & Alveolina cf. carantana, A. ruetimeyeri, A. aff. ruetimeyeri \\
\hline & 4 & Barren \\
\hline & 5 & Barren \\
\hline & 6 & Barren \\
\hline & 7 & Nummulites spp., Assilina spp. \\
\hline \multirow{7}{*}{$\begin{array}{l}\text { Middle depth (About } 40-80 \mathrm{~m} \text { ) } \\
\text { Middle shelf (Upper photic zone) }\end{array}$} & 8 & Barren \\
\hline & 9 & Nummulites spp. \\
\hline & 10 & Nummulites partschi \\
\hline & 11 & $\begin{array}{l}\text { Alveolina carantana, A. distefanoi, A. histrica, A. polatliensis, } \\
\text { A. ruetimeyeri, A. rugosa }\end{array}$ \\
\hline & 12 & Nummulites spp., Orbitolites spp., Rotalia spp. \\
\hline & 13 & Barren \\
\hline & 14 & Nummulites spp. \\
\hline \multirow{7}{*}{$\begin{array}{l}\text { Shallow (About 0-40 m) } \\
\text { Inner shelf (Upper photic zone) }\end{array}$} & 15 & Alveolina histrica, A. ruetimeyeri, A. sirelii sp. nov., Rotalia spp. \\
\hline & 16 & Nummulites spp., Orbitolites spp. \\
\hline & 17 & Gastropoda \\
\hline & 18 & $\begin{array}{l}\text { Alveolina axiampla, A. aff. bronnimanni, A. aff. cremae, } \\
\text { A. colatiensis, A. cuspidata, A. histrica, A. lehneri, A. oblonga, } \\
\text { A. rugosa, A. safranboluensis sp. nov., A. sirelii sp. nov. }\end{array}$ \\
\hline & 19 & $\begin{array}{l}\text { A. carantana, A. histrica, A. oblonga, A. ruetimeyeri, A. aff. } \\
\text { ruetimeyeri, Nummulites spp., Rotalia spp. }\end{array}$ \\
\hline & 20 & Barren \\
\hline & 21 & $\begin{array}{l}\text { Alveolina archiaci, A. barattoloi, A. cuspidata, A. oblonga, } \\
\text { A. polatliensis, A. rakoveci gueroli, A. ruetimeyeri, } \\
\text { A. cf. ruetimeyeri, A. rugosa, A. safranboluensis sp. nov., } \\
\text { A. sirelii sp. nov., A. sp. A, Assilina spp., Discocyclina spp., } \\
\text { Nummulites spp., Orbitolites spp., Rotalia spp., Gastropoda }\end{array}$ \\
\hline
\end{tabular}

occurrence of $A$. archiaci is from the Belendiz section of the lowermost-middle Cuisian from Karaman in Turkey by Sirel and Acar (2008) (Table 2). Alveolinid species associated with this taxon in Safranbolu Basin and the Belendiz section confine its range to the SBFZ 11. Restricted occurrence of the species to Central Tethyan region only, may imply that it is an endemic species. A. archiaci is recorded in the upper photic zone in the inner shelf area close to the coast line in Safranbolu Basin with several other alveolinid species.

Alveolina axiampla Drobne 1977

Plate 1_2

(Slide No.: A1903; Sample No.: 19)

1977 Alveolina aff. Axiampla Drobne, p. 65, fig. 36b, pl. 17, figs. 6-9; pl. 18, figs. 1-2.

2000 Alveolina axiampla Drobne, Önoğlu, p. 271.

2011 Alveolina axiampla Drobne, Drobne et al., p. 728.

Remarks: Alveolina axiampla is similar to A. ruetimeyeri and A. cylindriformis in terms of its test size. However, it is more cylindrical than A. ruetimeyeri and has larger proloculum than that of $A$. cylindriformis. The specimens recorded here are similar to Alveolina aff. Axiampla recorded by Drobne et al. (1977) in their length, width, elongation index and size of proloculus. $A$. aff. Axiampla has been recorded from the lowest Lutetian by Drobne et al. (1977) and the Cuisian by Drobne et al. (2011). The taxon has been recorded from the middle-upper Cuisian in Turkey by Önoğlu (2000). The range of the specimens corresponds to SBFZ 10 and indicates the upper photic zone.

Alveolina barattoloi Sirel and Acar 2008

Plate 1_3

(Slide No.: A2105; Sample No.: 21)

2008 Alveolina barattoloi Sirel and Acar, p. 46, figs. 4-6.

Remarks: Alveolina barattoloi possesses the same test and proloculum size with $A$. archiaci adamsi, however, the latter has greater elongation index. A. barattolo $i$ was first described by Sirel and Acar (2008) from the lowermiddle Cuisian argillaceous limestone of the Sakarya 

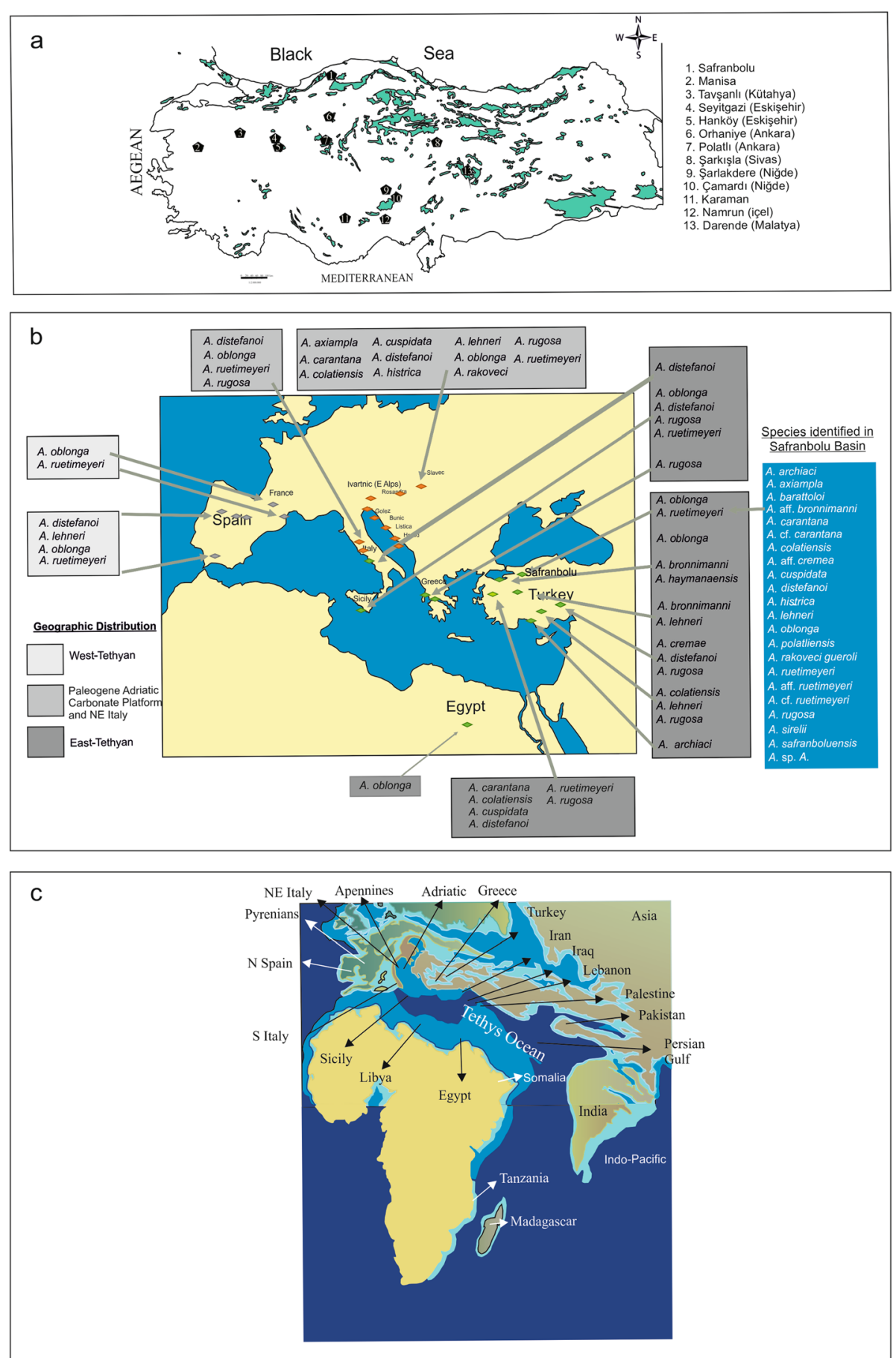

Fig. 6 a - Ypresian (Cuisian) and Lutetian Alveolina sites in Turkey (Eocene outcrops shaded); b - Alveolina sites along the Tethyan ocean margins; c - Alveolina species encountered in the Safranbolu Formation and in eastern, central and western Tethys (see text for sources)

section, Polatl, SW Ankara. The range of the species corresponds to SBFZ 10 and is recorded in the upper photic zone of the lower-middle Cuisian.

\section{Alveolina aff. bronnimanni}

Plate 1_4

(Slide No.: A1803; Sample No.: 18)
Remarks: Alveolina aff. Bronnimanni is similar to A. bronnimanni Sirel and Acar 2008 in its growth stage and the thickness of the basal layer; however it possesses a larger size and elongation index.

Alveolina carantana Drobne, Pavlovec \& Drobne 1977 


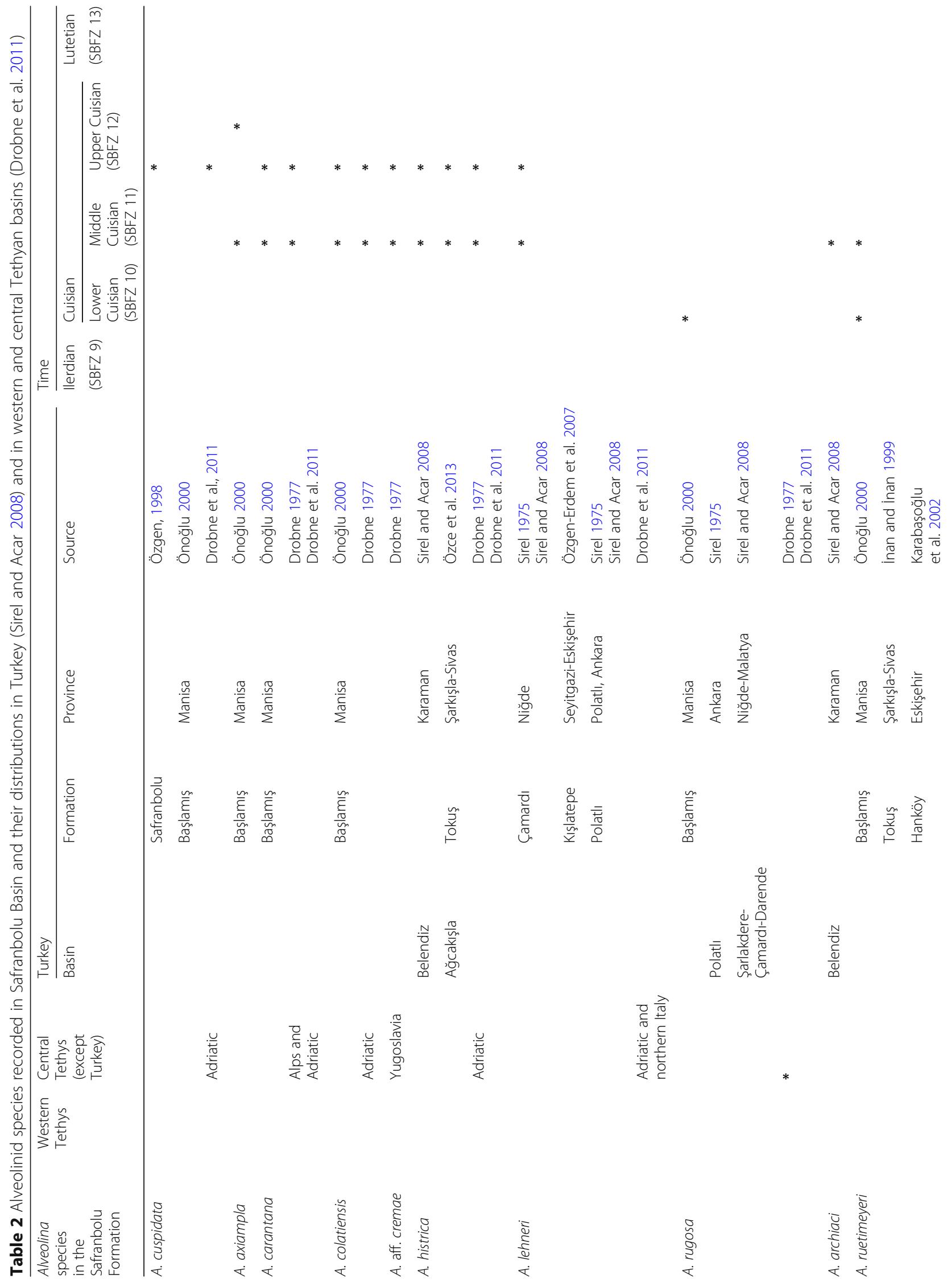




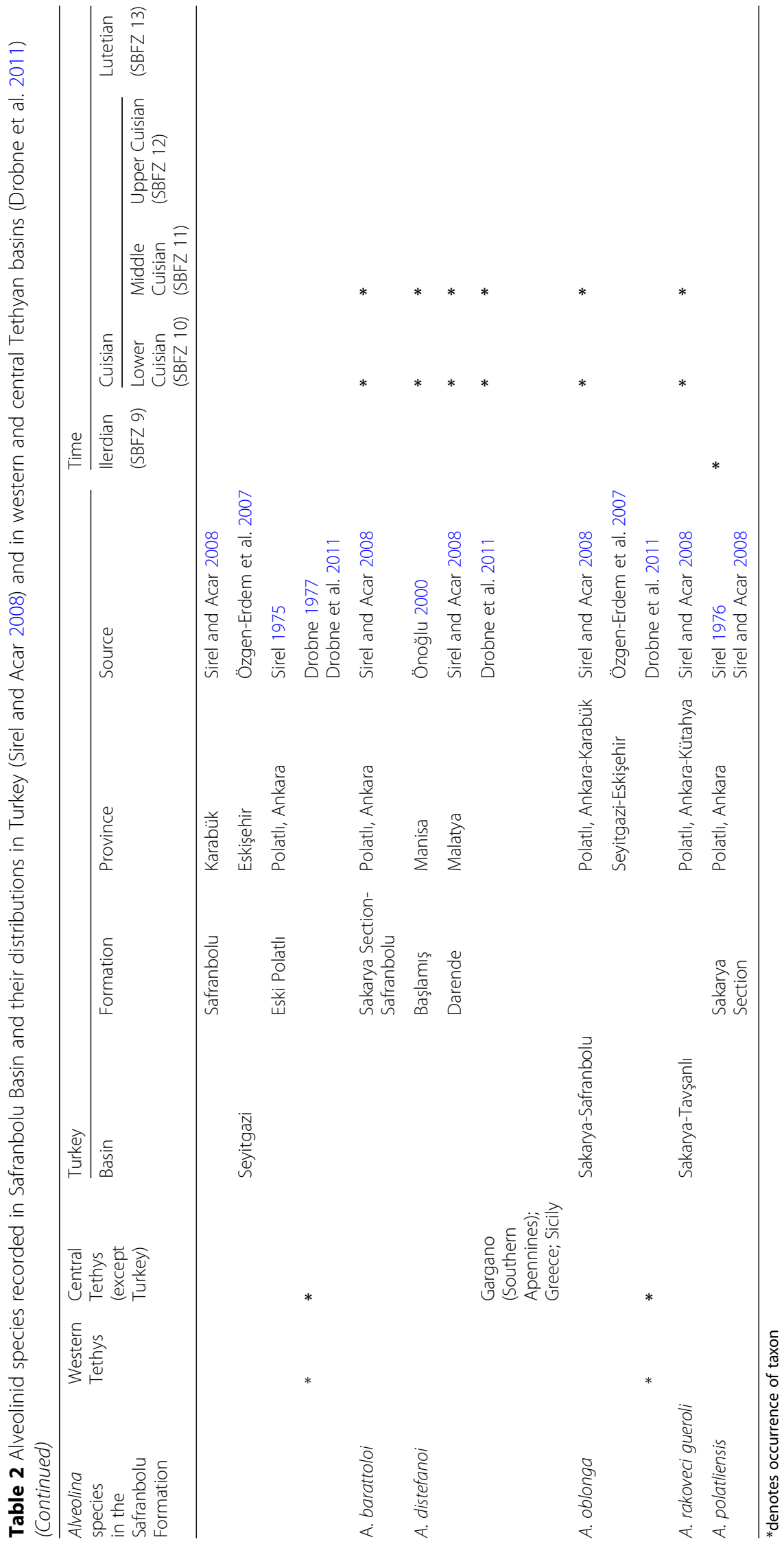




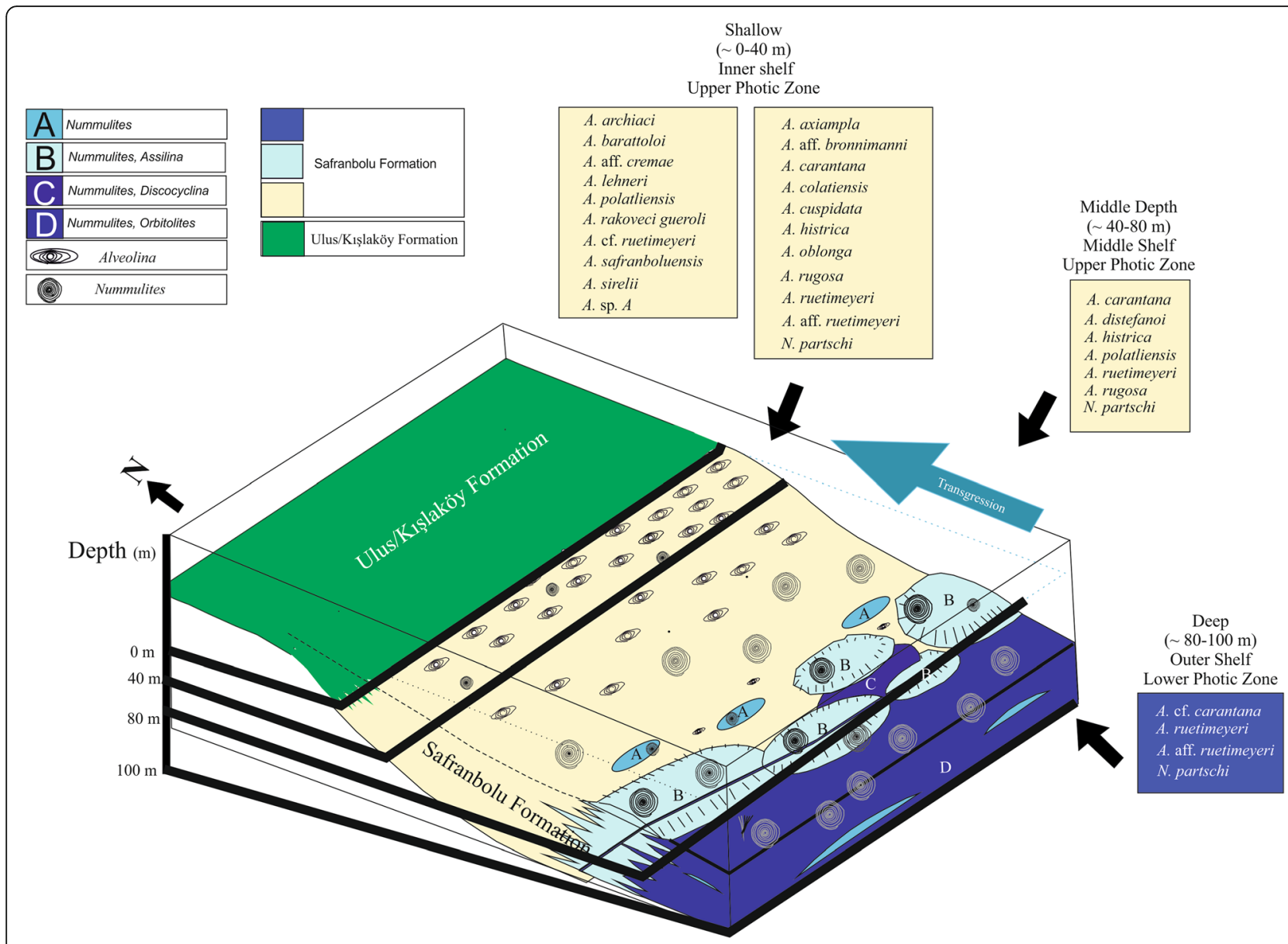

Fig. 7 Block-diagram showing the spatial distribution of alveolinid species in the study area

Plate 1_5

(Slide No.: A1107-A1910; Sample No.: 11, 19)

1977 Alveolina carantana Drobne, Pavlovec \&

Drobne, p. 31, pl. 2, figs. 1-7.

2000 Alveolina carantana Drobne, Önoğlu, p. 270.

2011 Alveolina carantana Drobne, Drobne et al., p. 728.

Remarks: Alveolina carantana and A. trempina are the same in the number of whorls and axial thicknesses. The former differs from the latter by its smaller elongation index and larger test size. The species has been reported from the eastern Alps and Adriatic region by Drobne et al. (1977) and Drobne et al. (2011). The two localities of $A$. carantana in Turkey are the Bașlamış Formation near Manisa recorded by Önoğlu (2000) and the Safranbolu Formation recorded by this study. The stratigraphic range of the species lies in the SBFZ 11-12 corresponding to the middle-late Cuisian age. A. carantana is recorded in the inner and middle-outer shelf areas, corresponding in upper and lower photic zones in the Safranbolu Basin.
Alveolina cf. carantana Drobne, Pavlovec \& Drobne 1977

Plate 1_6

(Slide No.: A0304; Sample No.: 3)

Remarks: Alveolina cf. carantana differs from $A$. carantana in having a smaller size, a smaller elongation index and the different growth stage.

Alveolina colatiensis Drobne, Pavlovec \& Drobne 1977

Plate 1_7

(Slide No.: A1814; Sample No.: 18)

1977 Alveolina colatiensis Drobne, Pavlovec \& Drobne, p. 72 , pl. 3, figs. $6-7$.

Remarks: Alveolina colatiensis is similar to A. cremae in terms of the test size, however, it differs from the latter by its smaller proloculum and greater number of whorls. A. colatiensis has been described from the middle Cuisian sediments of the Adriatic Platform by Drobne et al. (1977) and from the Başlamış Formation in Anatolia by Önoğlu (2000). The stratigraphic range of the species is the middle-upper Cuisian corresponding 

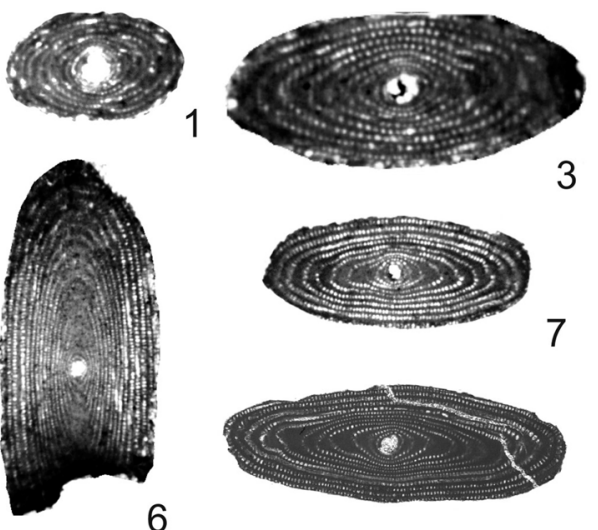

6
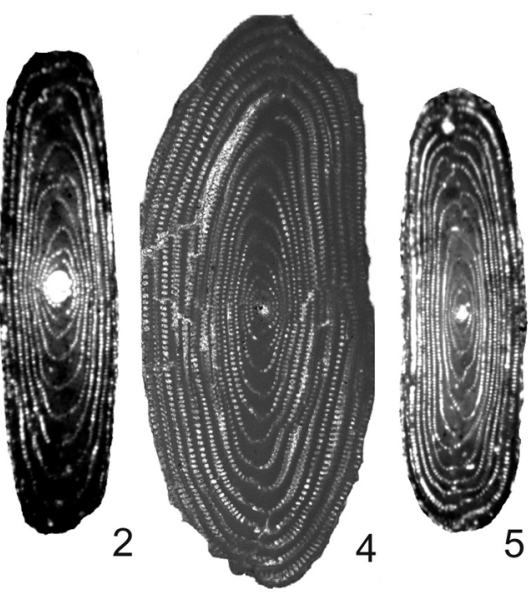

8
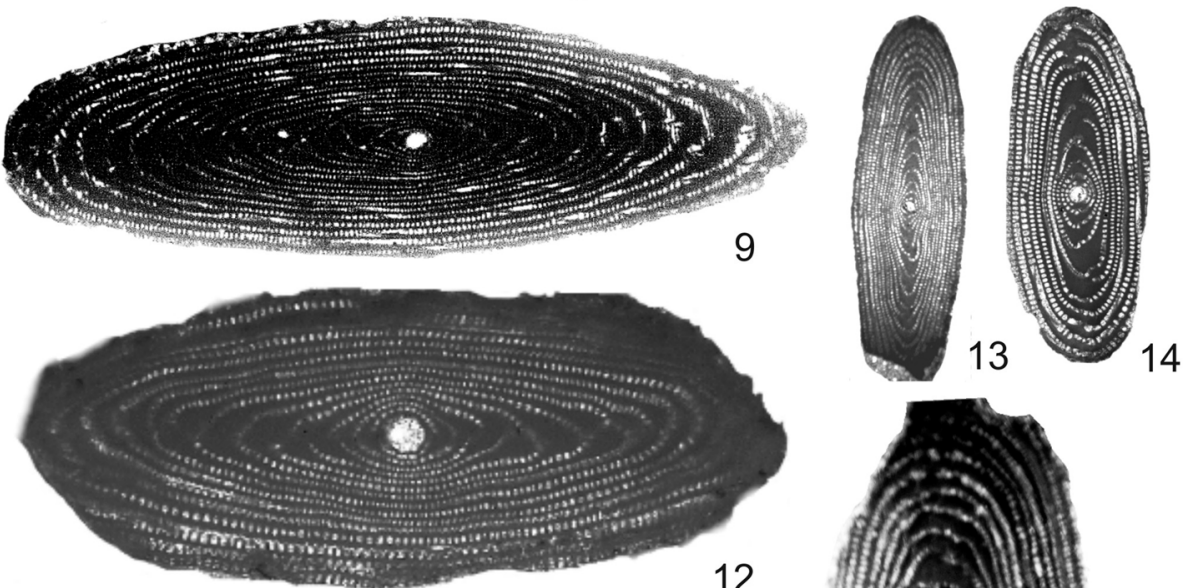

12
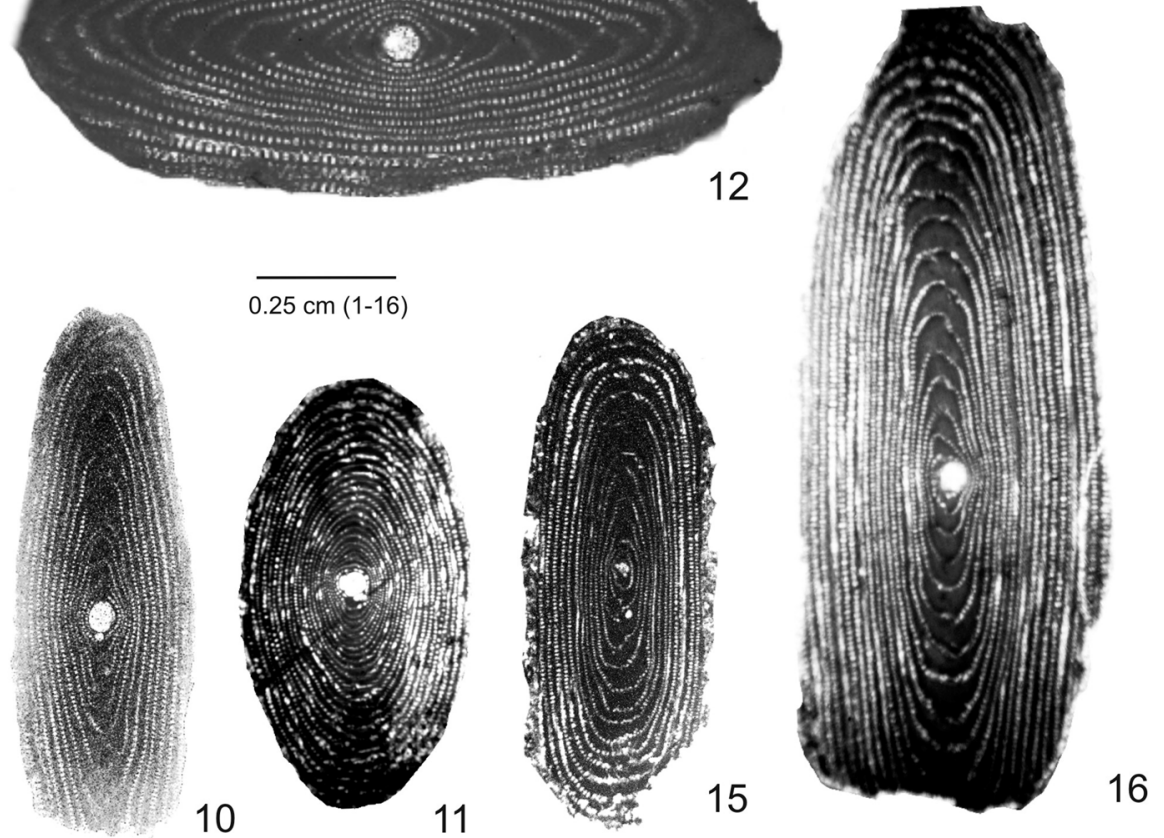

Plate 11 - Axial section, megalospheric form of Alveolina archiaci (Slide No.: A2102; Sample No.: 21); 2 - Alveolina axiampla (Slide No.: A1903; Sample No.: 19); 3 - Alveolina barattoloi (Slide No.: A2105; Sample No.: 21); 4 - Alveolina aff. bronnimanni (Slide No.: A1803; Sample No.: 18); 5 Alveolina carantana (Slide No.: A1107-A1910; Sample No.: 11, 19); 6 - Alveolina cf. carantana (Slide No.: A0304; Sample No.: 3); 7 - Alveolina colatiensis (Slide No.: A1814; Sample No.: 18); 8 - Alveolina aff. cremae (Slide No.: A1807; Sample No.: 18); 9 - Alveolina cuspidata (Slide No.: A1804A2112; Sample No.: 18, 21); 10 - Alveolina distefanoi (Slide No.: A1114; Sample No.: 11); 11 - Alveolina sp. A (Slide No.: A2107; Sample No.: 21); 12 - Alveolina histrica (Slide No.: A1108-A1502-A1803-A1905; Sample No.: 11, 15, 18, 19); 13 - Alveolina lehneri (Slide No.: A1809; Sample No.: 18); 14 - Alveolina oblonga (Slide No.: A1812-A1912-A2113; Sample No.: 18, 19, 21); 15 - Alveolina polatliensis (Slide No.: A1103-A2118; Sample No.: 11, 21); 16 - Alveolina rakoveci gueroli (Slide No.: A2119; Sample No.: 21). Scale bar is $0.25 \mathrm{~cm}$ for all 
to the SBFZ 11-12. A. colatiensis is recorded from the sediments deposited in the inner shelf area of the Safranbolu Basin.

\section{Alveolina aff. cremae}

Plate 1_8

(Slide No.: A1807; Sample No.: 18)

Remarks: The specimen recorded in this study (Plate 1_8) has larger size and smaller elongation index than Alveolina cremae Checchia-Rispoli 1905. It has similar morphological characteristics with Alveolina aff. Cremae reported by Drobne et al. (1977). A. cremae was reported from the middle Cuisian (SBFZ 11) sediments by Drobne et al. (1977) and Sirel and Acar (2008), and also from SBFZ 11-12 of the Čikola Canyon in North Dalmatian Basin by Španiček et al. (2017).

\section{Alveolina cuspidata Drobne 1977}

Plate 1_9

(Slide No.: A1804-A2112; Sample No.: 18, 21)

1977 Alveolina (Alveolina) cuspidata Drobne, p. 54, pl. 12, figs. 7-10.

1998 Alveolina cuspidata Drobne, Özgen, p. 74, pl. 1, fig. 6.

2000 Alveolina cuspidata Drobne, Önoğlu, p. 271.

2011 Alveolina cuspidata Drobne, Drobne et al., p. 749, pl. 2.

Remarks: The order of whorls and the axial thickness are similar in both Alveolina cuspidata and A. lehneri. A. cuspidata differs from the latter by its chamberlet size and a larger test size. A. cuspidata has been reported from the Adriatic Platform (Drobne et al. 2011), and the Başlamış Formation (Önoğlu 2000) and the Safranbolu Formation (Özgen 1998) in Anatolia. The stratigraphic range of the species corresponds to the upper Cuisian (SBFZ 12). A. cuspidata is found associated with several alveolinid species in the upper photic zone in shallowwater sediments of the Safranbolu Basin.

Alveolina distefanoi Checchia-Rispoli 1905

Plate 1_10

(Slide No.: A1114; Sample No.: 11)

1905 Alveolina distefanoi Checchia-Rispoli, p. 163, pl. 12, fig. 9.

2008 Alveolina distefanoi Checchia-Rispoli, Sirel and Acar, p. 73, pl. 71, figs. 9-14.

2000 Alveolina distefanoi Drobne, Önoğlu p. 271.

2011 Alveolina distefanoi Drobne, Drobne et al., p. 728.

Remarks: Alveolina distefanoi has similar axial thickness and order of whorls with $A$. rugosa, but larger proloculum and test size. A. distefanoi is one of the alveolinid species that have a wide geographic distribution in the Tethyan region. It has been reported from northern Spain, eastern Alps, Adriatic Platform, northeastern Italy, southern Apennines, Greece and Sicily (Drobne et al. 2011). This species has also been recorded from the Başlamış Formation by Önoğlu (2000) and from Darende-Malatya by Sirel and Acar (2008) in Anatolia. The stratigraphic range of the species is the lower-middle Cuisian corresponding to SBFZ 10-11, and is found in the middle shelf area in the Safranbolu Formation.

Alveolina sp. A

Plate 1_11

(Slide No.: A2107; Sample No.: 21)

Remarks: Alveolina sp. A resembles A. haymanensis Sirel 1976, however, the specimen recorded in this study possess more tightly coiled adult whorls, and larger size and elongation index than the latter. $A$. sp. $A$ is found in the upper photic zone of the Safranbolu Basin.

\section{Alveolina histrica Drobne 1977}

Plate 1_12

(Slide No.: A1108-A1502-A1803-A1905; Sample No.: $11,15,18,19)$

1977 Alveolina (Alveolina) histrica Drobne, p. 44, pl. 7, figs. 16-19; pl. 8, fig. 1.

2008 Alveolina histrica Drobne, Sirel and Acar, p. 74, pl. 57, fig. 7; pl. 58, fig. 4.

2011 Alveolina histrica Drobne, Drobne et al., p. 728. 2013 Alveolina histrica Drobne, Özce et al., p. 196.

Remarks: Alveolina histrica and A. rakoveci are similar in the proloculum size and the order of their whorls; but $A$. histrica differs from the latter by having a more cylindrical test size. A. histrica has been reported from the Adriatic Platform (Drobne 1977; Drobne et al. 2011), the Belendiz (Sirel and Acar 2008) and the Şarkışla-Sivas (Özce et al. 2013) in Anatolia, corresponding to the middle-upper Cuisian sediments of SBFZ 11-12. A. histrica is found in the inner shelf area of the Safranbolu Basin.

\section{Alveolina lehneri Hottinger 1960}

Plate 1_13

(Slide No.: A1809; Sample No.: 18)

1960 Alveolina lehneri Hottinger, p. 147, pl. 13, figs. 7-9.

1975 Alveolina lehneri Hottinger, Sirel, p. 190.

2007 Alveolina lehneri Hottinger, Özgen-Erdem et al., p. 924, pl. 9-e.

2008 Alveolina lehneri Hottinger, Sirel and Acar, p. 74, pl. 72, figs. 1-5.

2011 Alveolina lehneri Hottinger, Drobne et al., p. 249, pl. 2.

Remarks: Alveolina lehneri is most similar to A. ruetimeyeri in terms of its test size. However, it has smaller proloculum and chamberlets but larger number of whorls. A. lehneri has a wide geographic distribution in the sub-basins of the Tethys region from northern Spain to the Adriatic Platform and northern Italy (Drobne et al. 2011). The species has also been reported from various localities in Turkey, e.g., from Polatlı (Ankara) and Çamardı (Niğde) by Sirel (1975) and Sirel and Acar (2008), from Kışlatepe (Seyitgazi-Eskişehir) by Özgen- 
Erdem et al. (2007). The stratigraphic range of this species corresponds to the middle-upper Cuisian sediments of SBFZ 11-12. A. lehneri is recorded in the upper photic zone in the Safranbolu Basin.

Alveolina oblonga D’Orbigny 1826

Plate 1_14

(Slide No.: A1812-A1912-A2113; Sample No.: 18, 19, 21)

1826 Alveolina oblonga d'Orbigny, Tableau methodique, p. 306.

2001 Alveolina oblonga d'Orbigny, Drobne et al., p. 749, pl. 2.

2007 Alveolina oblonga d'Orbigny, Özgen-Erdem et al., p. 921, pl. 8-f.

2008 Alveolina oblonga d'Orbigny, Sirel and Acar, p. 67 , pl. 63, figs. $1-5$; pl. 64, figs. 1-4.

Remarks: The test size and proloculum size are the same in both Alveolina oblonga and A. ruetimeyeri. The former species is distinguished from the latter by its different number of whorls in the growth stages. A. oblonga has a wide geographic distribution in the sub-basins of the Tethys region including northern Spain, southern France, the Adriatic Platform, northern Italy, Sicily and Eygpt (Drobne et al. 2011). The species has also been reported from various places in Turkey, such as Sakarya, Polatll, Karabük (Sirel and Acar 2008) and SeyitgaziEskişehir (Özgen-Erdem et al. 2007). The stratigraphic range of the species corresponds to the lower-middle Cuisian of SBFZ 10-11. A. oblonga is recorded in the shallow-water sediments of the Safranbolu Basin.

\section{Alveolina polatliensis Sirel 1976}

Plate $1 \_15$

(Slide No.: A1103-A2118; Sample No.: 11, 21)

1976 Alveolina polatliensis Sirel, p. 19, pl. II, figs. 1, 3, $4,6$.

2008 Alveolina polatliensis Sirel, Sirel and Acar, p. 48, pl. 36, figs. 16-18; pl. 37, figs. 1-3.

Remarks: The oval shaped test and small size of their chamberlets are similar in both Alveolina polatliensis and A. pieroi. A. polatliensis differs from $A$. pieroi by smaller axial thickness and possessing more whorls in the same test size. A. polatliensis was reported only from the Eski Polatlı Formation in Ankara by Sirel (1976), and was assigned to a middle Ilerdian age, corresponding to SBFZ 9 (Sirel and Acar 2008). This species here is found in the zones from SBFZ 9 extending to SBFZ 12 in this study. A. polatliensis is recorded in the upper photic zone close to the coast line in the Safranbolu Basin with several other alveolinid species.

\section{Alveolina rakoveci gueroli Drobne 1977}

Plate 1_16

(Slide No.: A2119; Sample No.: 21)

1977 Alveolina rakoveci gueroli, p. 46, pl. 8, figs. 6-8; pl. 9, figs. 1-5.
2008 Alveolina rakoveci gueroli Drobne, Sirel and Acar, p. 79, pl. 55, figs. 1, 2.

Remarks: The test size of Alveolina rakoveci gueroli, A. cayrazensis and A. lehneri are similar. A. rakoveci gueroli differs from the latter two species by greater axial thickness and chamberlets, and lesser number of whorls. A. rakoveci gueroli has been reported from the lowermiddle Cuisian strata corresponding to the SBFZ 10-11 in the Tavşanlı Area (Kütahya, West Anatolia) by Sirel and Acar (2008). This species is recorded in the inner shelf area of the Safranbolu Basin. A. rakoveci has been reported from the Cuisian strata corresponding to the SBFZ 12 in the Adriatic Platform by Drobne et al. (1977) and Drobne et al. (2011). This species is recorded also in the inner shelf area of the Safranbolu Basin.

Alveolina ruetimeyeri Hottinger 1960

Plate 2_1

(Slide No.: A0306-A1106-A1507-A2123; Sample No.: $3,11,15,21)$

1960 Alveolina rütimeyeri Hottinger, p. 158, pl. 9, figs. 17, 18; pl. 11, figs. 13-15; pl. 14, figs. 20-22; pl. 15, figs. 5,6 .

1977 Alveolina ruetimeyeri Hottinger, Drobne, p. 64, pl. 17, figs. 2-5.

1999 Alveolina ruetimeyeri Hottinger, İnan and İnan, p. 125.

2002 Alveolina ruetimeyeri Hottinger, Karabaşoğlu et al., p. 141.

2011 Alveolina ruetimeyeri Hottinger, Drobne et al., p. 749, pl. 2.

Remarks: The oval shape and small proloculum make Alveolina ruetimeyeri different from A. cremae. A. ruetimeyeri has a wide geographical distribution both in the Tethyan region and in Anatolia. It has been reported from Spain, France to the Adriatic Platform, northeastern Italy and Sicily (Drobne 1977; Drobne et al. 2011). Meanwhile, Tokuş (Şarkışla-Sivas) (İnan and İnan 1999), Başlamış (Manisa) (Önoğlu 2000), Hanköy (Karabaşoğlu et al. 2002), Seyitgazi-Eskişehir (Özgen-Erdem et al. 2005), Safranbolu (Sirel and Acar 2008), and this study area are the locations in Anatolia where the species have been recognized. A. ruetimeyeri has a stratigraphic range of the lower-middle Cuisian corresponding to the SBFZ 10-11. It is recorded in the lower photic zone in the middle to outer shelf of the Safranbolu Basin.

\section{Alveolina aff. ruetimeyeri}

Plate 2_2

(Slide No.: A0305-A1907; Sample No.: 3, 19)

Remarks: Alveolina aff. Ruetimeyeri differs from A. cf. ruetimeyeri Hottinger 1960 by having larger size and elongation index. And, A. aff. Ruetimeyeri is recorded both in the lower and upper photic zone in the outer and inner shelf area of the Safranbolu Basin.

Alveolina cf. ruetimeyeri Hottinger 1960 


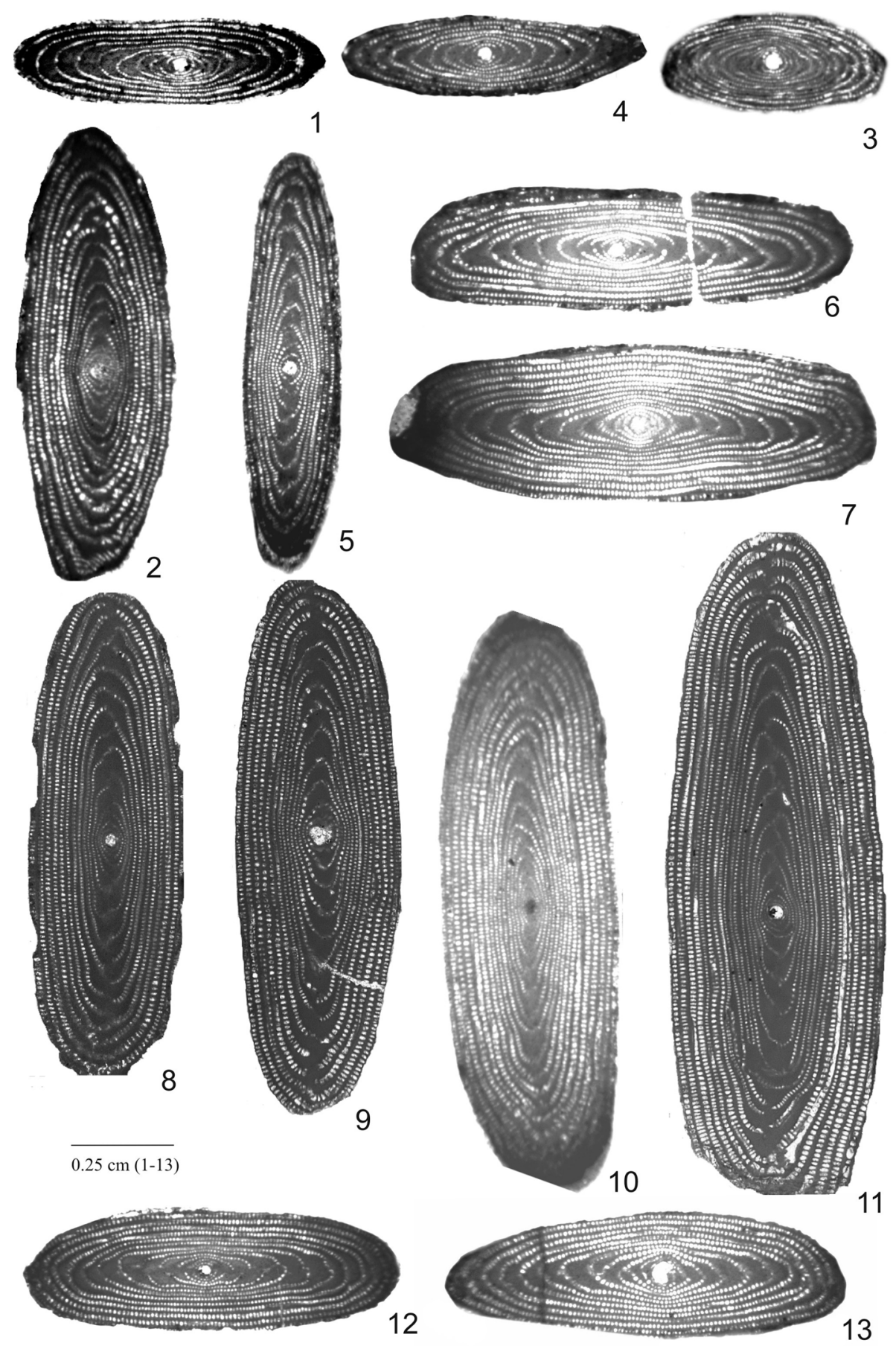

Plate 21 - Axial section, megalospheric form of Alveolina ruetimeyeri (Slide No.: A0306-A1106-A1507-A2123; Sample No.: 3, 11, 15, 21); 2 - Alveolina aff. ruetimeyeri (Slide No:: A0305-A1907; Sample No.: 3, 19); 3 - Alveolina of. ruetimeyeri (Slide No.: A2118; Sample No.: 21); 4 - Alveolina rugosa (Slide No.: A1112A1813-A2111; Sample No.: 11, 18, 21); 5-13 - Alveolina sirelii sp. nov. (Slide No.: A1508-A1814-A2125; Sample No.: 15, 18, 21). Scale bar is 0.25 cm for all

Plate 2_3

(Slide No.: A2118; Sample No.: 21)

1960 Alveolina ruetimeyeri Hottinger, p. 158, pl. 9, figs. 17 , 18; pl. 11, figs. $13-15$; pl. 14, figs. 20-22; pl. 15, figs. 5,6 .
Remarks: The specimen recorded in this study has a similar proloculus with Alveolina ruetimeyeri, but possesses smaller axial and longer equatorial diameter. $A$. cf. ruetimeyeri is recorded in the inner shelf area of the Safranbolu Basin. 


\section{Alveolina rugosa Hottinger 1960}

\section{Plate 24}

(Slide No.: A1112-A1813-A2111; Sample No.: 11, 18, 21)

1960 Alveolina rugosa Hottinger, p. 151, pl. 10, fig. 14; pl. 11, fig. 9; pl. 14, fig. 23.

1975 Alveolina rugosa Hottinger, Sirel, p. 190.

1977 Alveolina rugosa Hottinger, Drobne, p. 54, pl. 12, figs. 12-14.

2008 Alveolina rugosa Hottinger, Sirel and Acar, p. 76, pl. 73, figs. 1-9.

2011 Alveolina rugosa Drobne, Drobne et al., p. 728.

Remarks: Alveolina rugosa is similar to A. ruetimeyeri in terms of the number of their whorls and axial thicknesses. A. rugosa is distinguished from the latter species by having more conical shape. A. rugosa has been reported from the Adriatic Platform and northeastern Italy (Drobne 1977; Drobne et al. 2011), and, from Turkey (Başlamış Formation (Manisa), Önoğlu 2000; Polatlı (Ankara), Sirel 1975; Şarlakdere and Çamardı (Niğde) and Darende (Malatya), Sirel and Acar 2008). The stratigraphic range of the species is the lower-middle-upper Cuisian corresponding to the SBFZ 10-12. And the species is recorded in the middle shelf area of the Safranbolu basin.

\section{Alveolina sirelii sp. nov.}

Plate 2_5-Plate 2_13; Plate 3_1-Plate 3_2

(Slide No.: A1508-A1814-A2125; Sample No.: 15, 18, 21)

Derivation of name: The species is dedicated to Dr. Ercüment Sirel who has substantial palaeontological contributions to larger foraminifera.

Holotype: Axial section of megalospheric form, Eskişehir Osmangazi University, Micropalaeontology Laboratory.

Type locality: Sample Number: 15, 18 and 21, Safranbolu Formation, SE Safranbolu, northern Turkey.

Type level: Lower Cuisian (SBFZ 10).

Diagnosis: The medium-sized tests of megalospheric specimens have elongated forms with rounded poles. The axial diameter is $10.2-18.8 \mathrm{~mm}$, equatorial diameter is $2.3-5.3 \mathrm{~mm}$; the index of elongation is $3.2-3.4$ in the fifth and 4.0-4.6 in the tenth whorl. The proloculus is large and spherical, with $0.3-0.4 \mathrm{~mm}$ in diameter, followed by one spherical-subspherical whorl in nepionic stage. In the following adult stage, the axial part of the basal layer becomes thicker as opposed to the basal layer of the equatorial spirals, and the whorl becomes elongated. The size of the chamberlets increases from the first to the last whorl. Their cross-sections are circularsubcircular in the early whorls, but become upright-oval at the last whorls. The description of the microspheric generation is based on one axial section. The microspheric form has elongated whorls of growth stage and the test shape is similar to megalospheric form. The large-sized test of microspheric form has an elongated shape. The axial diameter is $14.3 \mathrm{~mm}$, and equatorial diameter is $4.3 \mathrm{~mm}$. The index of elongation is 3.3 in the sixteenth whorl.
Remarks: Alveolina sirelii differs from A. cuspidata in its shape; the shape is elongated with rounded poles in the former, however, is fusiform in the latter. A. sirelii differs from $A$. histrica and $A$. rakoveci by size; the diameters of the latter species are both longer than $1 \mathrm{~cm}$. $A$. sirelii has greater elongation index and smaller chamberlets than A.aff. Ruetimeyeri.

Distrubution: Alveolina sirelii has been recorded in the upper photic zone in the inner shelf area of the Safranbolu Basin, associated with abundant alveolinid species.

\section{Alveolina safranboluensis sp. nov.}

Plate 3_3-Plate 38

(Slide No.: A1816-A2112; Sample No.: 18, 21)

Derivation of name: Town Safranbolu where the samples were collected.

Holotype: Axial section of megalospheric form, Eskişehir Osmangazi University, Micropalaeontology Laboratory.

Type locality: Sample Number: 18 and 21, Safranbolu Formation, SE Safranbolu, northern Turkey.

Type level: Lower Cuisian (SBFZ 10).

Description: The megalospheric generation of Alveolina safranboluensis has a middle sized, slightly elongated ovoid test with an axial diameter of $10.0-12.3 \mathrm{~mm}$ and equatorial diameter of $3.7-4.6 \mathrm{~mm}$. The index of elongation is $2.3-3.5$ in the fifth and 3.0-3.8 in the tenth whorl. The spheric proloculus, with $0.3-0.5 \mathrm{~mm}$ in diameter, is followed by two tightly coiled spheric whorls of the nepionic stage. The axial thickening becomes thicker in comparison with the basal layer of equatorial spirals in the following six or seven elongated whorls. In the last five to six adult whorls, the thickening of the basal layer becomes narrower at the axial as well as at the equatorial sectors. The cross-sections of the chamberlets are generally circular-subcircular, but become angular towards the outer whorls.

Remarks: Alveolina safranboluensis differs from A. sirelii with its larger proloculum, different juvenile stage, and smaller elongation index resulted from a thinner basal layer in its adult stage.

Distribution: Alveolina safranboluensis has been recorded in the upper photic zone in the inner shelf area of the Safranbolu Basin associated with abundant alveolinid species.

Family: Nummulitidae de BLAINVILLE, 1825

Subfamily: Nummulitinae de BLAINVILLE, 1825

Genus: Nummulites LAMARCK, 1801

Nummulites partschi De la Harpe 1880

Plate 3_9-Plate 3_14

(Slide No.: N0204-N1002; Sample No.: 2, 10)

1880 Nummulites partschi, de la Harpe, pl. 3, figs. 1, 2, 2a, 5, 5a, 6a.

Remarks: Test diameter is $5.4 \mathrm{~mm}$; proloculum is 0.5 mm consisting of 4 whorls. Rectangular chamberlets are 


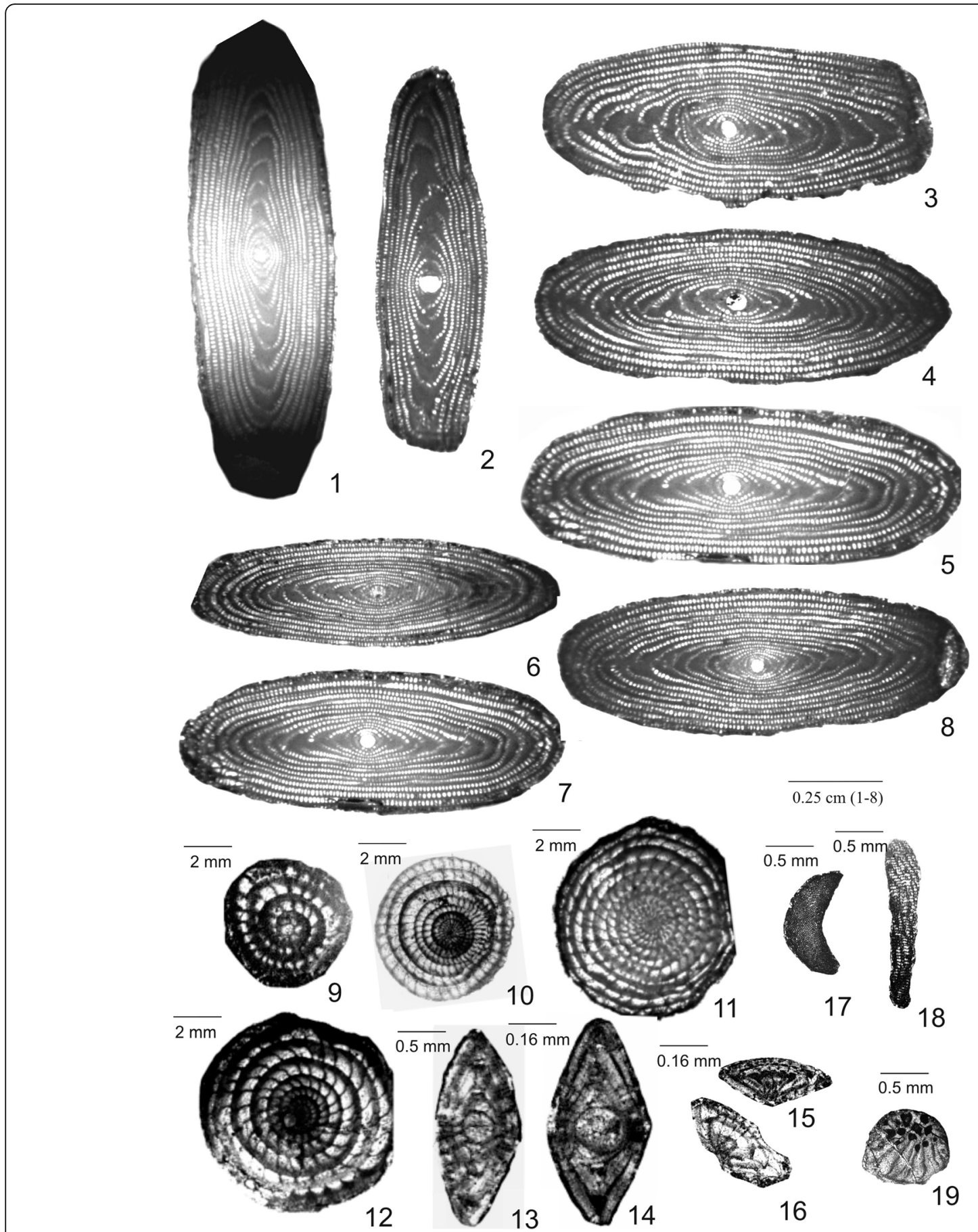

Plate 3 1-2 - Axial section, megalospheric form of Alveolina sirelii sp. nov. (Slide No.: A1508-A1814-A2125; Sample No:: 15, 18, 21); 3-8 Alveolina safranboluensis sp. nov. (Slide No.: A1816-A2112; Sample No.: 18, 21); Scale bar is $0.25 \mathrm{~cm}$ for 1-8; 9 - Equatorial section, megalospheric form of Nummulites partschi (Slide No.: N0204; Sample No.: 2); 10-12 - Equatorial section, microspheric form of Nummulites spp. (Slide No: N0702-N0901-N1201-N1401-N1602-N1901-N2101; Sample No.: 7, 9, 12, 14, 16, 19, 21); Scale bar is 2 mm for 9-12; 13 - Equatorial section, megalospheric form of Nummulites partschi (Slide No.: N1002; Sample No.: 10); Scale bar is $0.5 \mathrm{~mm}$; 14 - Equatorial section, megalospheric form of Nummulites spp. (Slide No.: N1401-N1602-N1901-N2101; Sample No.: 14, 16, 19, 21); 15-16 - Equatorial section of Rotalia spp. (Slide No:: R1201R1501-R1901-R2101; Sample No.: 12, 15, 19, 21); Scale bar is $0.16 \mathrm{~mm}$ for 14-16; 17 - Equatorial section of Discocylina spp. (Slide No.: D2101; Sample No.: 21); 18 - Equatorial section of Orbitolites spp. (Slide No.: O1201-O1601-O2101; Sample No.: 12, 16, 21 ); 19 - Equatorial section of Assilina spp. (Slide No.: S0701-S2101; Sample No.: 7, 21). Scale bar is $0.5 \mathrm{~mm}$ for 17-19 
separated by oblique septa. Specimes here are defined by their equatorial and axial sections of the macrospheric forms.

Nummulites spp. LAMARCK, 1801

Plate 3_10-12-Plate 3_14

(Slide No: N0702-N0901-N1201-N1401-N1602-

N1901-N2101; Sample No: 7, 9, 12, 14, 16, 19, 21)

Remarks: Diameter of lenticular shells is $5-9 \mathrm{~mm}$; microspheric forms consist of 7-8 whorls; rectangular chamberlets are separated by oblique septa. Size of chamberlets increases towards the last round.

Family: Rotaliidae EHRENBERG, 1839

Subfamily: Rotaliinae EHRENBERG, 1839

Genus: Rotalia LAMARCK, 1804

\section{Rotalia spp.}

Plate 3_15-Plate 3_16

(Slide No.: R1201-R1501-R1901-R2101; Sample No.: $12,15,19,21)$

Remarks: The specimens have trochospiral coiling consisting of 4 whorls, with about 10 chamberlets in each whorl. The diameter of test size is $4 \mathrm{~mm}$.

Family: Discocyclinidae GALLOWAY, 1928

Genus: Discocyclina GUMBEL, 1870

Discocyclina spp.

Plate 3_17

(Slide No.: D2101; Sample No.: 21)

Remarks: Disc-shaped test has a very tight planispiral coiling; and test diameter is $4.8 \mathrm{~mm}$.

Family: Soritoidae EHRENBERG, 1839

Genus: Orbitolites LAMARCK, 1801

\section{Orbitolites spp.}

Plate 318

(Slide No.: O1201-O1601-O2101; Sample No.: 12, 16, 21)

Remarks: Disc-shaped test has 6 whorls consisting of numerous small chamberlets.

Genus: Assilina D'ORBIGNY 1839

Assilina spp.

Plate 3_19

(Slide No.: S0701-S2101; Sample No.: 7, 21)

Remarks: Transverse section of the disc-shaped, flat, granular form of Assilina spp. is illustrated in Plate 3_19; diameter of the test is $3.45 \mathrm{~mm}$.

\subsection{Stratigraphical and palaeoenvironmental interpretations}

The biostratigraphical, ecological and geographical distributions of the genus Alveolina from Turkey (Sirel 1998; Sirel and Acar 2008) and other localities (sub-basins) in the shallow zones of Tethyan margins (Spain, France, Italy, Greece, Libya, Egypt, Somalia, Tanzania, Iran, Iraq, Lebanon, Palestine, Pakistan, and the Persian Gulf) (Drobne et al. 2011) (Fig. 6a and b) were analyzed here in detail for the comparisons of the taxa found in the Safranbolu Formation. Many of the species recorded in the abovementioned areas were well-correlated with the taxa recorded in the study area.

Palaeontological analysis of the samples from the Safranbolu Formation yielded well-preserved benthic foraminifera belonging to the genera Alveolina, Nummulites, Assilina, Rotalia, Disclocyclina and Orbitolites. Among these, Alveolina is the most diversified genus which is represented by 16 species: Alveolina archiaci, A. axiampla, A. barattoloi, A. carantana, A. colatiensis, A. cuspidata, A. distefanoi, A. histrica, A. lehneri, A. oblonga, A. polatliensis, A. rakoveci, A. ruetimeyeri, A. rugosa, A. safranboluensis and $A$. sirelii. Comparisons of the alveolinid assemblage of the Safranbolu Formation with those assemblages previously reported from both Turkey (Fig. 6a) and other Tethyan sub-basins (Fig. 6b and c) revealed that Alveolina arciachi, A. barattoloi, A. polatliensis, A. safranboluensis, and $A$. sirelii have a restricted geographic distribution in Anatolia (Figs. 5 and 6).

Four samples (Sample No.: 1, 4, 5, and 6) out of seven (Sample No.: 1-7), collected from the 9-m-thick top of the section, were barren of fossils. Only one sample (Sample No.: 3) yielded three alveolinid taxa: Alveolina ruetimeyeri, $A$. aff. Ruetimeyeri, and $A$. cf. carantana. However, two samples (Sample No.: 2 and 7) at this interval yielded abundant Nummulites and Assilina species which are known as benthic foraminifera preferring environments deeper than $\sim 80 \mathrm{~m}$ of sea, i.e. outer shelf areas. The presence of only a few alveolinid taxa beyond their shallow-depth habitats might have been due to their transportation along the shelf slope.

Similar to the first sample set (Sample No.: 1-7) on the top of the studied section, only one sample (Sample No.: 11) among six (Sample No.: 8-13) collected from the next 8-m-thick interval comprised alveolinid taxa. Alveolinid fossils in this interval of the section was more diverse and more abundant than the first sample set taken from the upper interval; but less diverse and less abundant than the 11-m-thick bottom section (Sample No.: 14-21). The recorded taxa were Alveolina archiaci, A. carantana, A. distefanoi, A. histrica, A. polatliensis, $A$. ruetimeyeri, and $A$. rugosa. All of the assemblage, with the exception of only $A$. distefanoi, were also recorded in the bottom-interval. Alveolinids were accompanied by a few Nummulites, Orbitolites and Rotalia species in this zone. Diversity of the fossil content and its position in the section may denote a middle shelf setting, down to the depths of $\sim 40-80 \mathrm{~m}$ in the upper photic zone (Fig. 7).

Four samples (Sample No.: 15, 18, 19 and 21) yielded the most abundant and diverse alveolinid species, including Alveolina archiaci, A. axiampla, A. barattoloi, A. carantana, A. colatiensis, A. cuspidata, A. histrica, A. lehneri, A. oblonga, A. polatliensis, A. rakoveci gueroli, A. ruetimeyeri, A. rugosa, A. rugosa, A. safranboluensis, $A$. sirelii and $A$. sp. $A$, collected from the 11-m-thick bottom-interval of the 
studied section. In addition to above species, Alveolina aff. Bronnimanni, A. aff. Cremae, A. aff. Ruetimeyeri and A. cf. ruetimeyeri were also recorded. The assemblage here was accompanied by only a few larger benthic taxa belonging to Nummulites, Assilina, Discocylina, Rotalia, Orbitolites, and Gastropoda (Table 1).

Recent alveolinids live down to a depth of about $60 \mathrm{~m}$, and, the diversity and abundance of the fossil forms usually culminate at the depth down to $\sim 40 \mathrm{~m}$, in the shallowest part of shelves, in lagoonal or fore-reef settings (Hottinger 1960; Tosquella et al. 1990; Özgen-Erdem 2008; Di Carlo et al. 2010; Drobne et al. 2011). Whereas other larger benthic foraminifera such as Nummulites, Assilina, Orbitoites are known inhabiting in environments deeper than $\sim 80 \mathrm{~m}$ in the lower photic zone. Most of the studied section of the Safranbolu Formation is therefore, interpreted as a restricted platform of the basin in the upper photic zone based on the diversity and abundance of alveolinids and other larger benthic taxa (Fig. 7). These evidences reveal a transgressive sequence during the time interval of the deposition of SBFZ 10-12.

The stratigraphic distribution of alveolinid taxa reported from the shallow zones of the eastern, central and western Tethyan margins indicated a stratigraphic range from SBFZ 9 to SBFZ 13 for the Safranbolu Formation (Table 2; Fig. 6). Among 16 taxa recorded in the Safranbolu Formation, Alveolina polatliensis had the oldest stratigraphic record of the late Ilerdian age corresponding to the SBFZ 9, whereas A. axiampla developed in the upper Cuisian and the lower Lutetian corresponding to the SBFZ 12 and SBFZ 13. The stratigraphic distribution of the rest of alveolinids in the Safranbolu Formation culminated in the SBFZ 10-12, synchronous to a time interval of the Cuisian and particularly of the middle-late Cuisian age (Table 2). This interval appeared to be correlatable to the acme zone defined by Drobne et al. (2011) at the SBFZ 11-12 for the Adriatic Platform.

\section{Conclusions}

Twenty taxa belonging to the genus Alveolina along with the genera Nummulites, Assilina, Rotalia, Disclocyclina and Orbitolites were described from the Safranbolu Formation of the Cuisian age (SBFZ 10-12) in this study. Two alveolinid species, A. safranboluensis and A. sirelii, were newly described. Comparison of the spatial distributions of these alveolinid species with those reported from other sub-basins of the Tethyan realm revealed that most taxa have common occurrences in the entire region, except Alveolina archiaci, A. barattoloi and A. polatliensis; and, Alveolina archiaci, A. barattoloi, A. polatliensis together with the newly described species here were restricted only to Anatolia. The Safranbolu Basin also emerged as one of the most prolific sites comprising larger benthic foraminifera among the Eocene basins in Anatolia. Although the time range of the species recorded was from the late Ilerdian to the early Lutetian (SBFZ 9-13), the culmination occurred in the Cuisian in the zones of SBFZ 11-12. Ecological preferences of the fossil assemblage revealed that the Safranbolu Formation was deposited under transgressive conditions.

\section{Acknowledgements \\ The authors wish to express their appreciation to Dr. Ercüment Sirel and Dr. Ali Deveciler from the Geology Department, Ankara University for their keen interest and sincere help during the course of the study. They have provided valuable support and constructive comments.}

\section{Authors' contributions}

Field work, sample collection, result interpretation, and concluding remarks were carried out by both $\mathrm{KO}$ and $\mathrm{HK}$ together. $\mathrm{KO}$ conducted the microscope study. The manuscript has been read and approved by both authors; and, there are no other persons who satisfied the criteria for authorship but are not listed.

\section{Funding}

This study was supported by and carried out under the Graduate Studies of Eskişehir Osmangazi University, Council of Higher Education of Turkey.

\section{Availability of data and materials}

The manuscript is an outcome of a Master of Science Thesis submitted to the Graduate Studies of Eskişehir Osmangazi University by the first author Kubra Okur who studied under the supervision of Dr. Hatice Kutluk. Specimens were collected from the study area during the field work and stored in the Micropaleontology Laboratory in the Department of Geology, Eskişehir Osmangazi University.

\section{Competing interests}

The authors declare that they have no competing interests.

Received: 18 March 2019 Accepted: 8 January 2020

Published online: 21 February 2020

\section{References}

Avşar, N. 1992. Paleogene benthic foraminiferal fauna of the Namrun (içel) region. Mineral Research and Exploration Bulletin 114: 127-144.

Bozkurt, E., and S.K. Mittwede. 2001. Introduction to the geology of Turkey - A synthesis. International Geology Review 43 (7): 578-594.

Canik, B. 1977. Hydrogeological investigation of Bolu hot water spring. PhD thesis. Ankara: Faculty of Science, Ankara University.

Cerit, O. 1983. Geological investigation of Mengen (Bolu N) Region. PhD thesis. Ankara: Hacettepe University.

Checchia-Rispoli, G. 1905. Sopra alcune Alveoline eoceniche della Sicilia. Palaeontographia Italica 11: 147-167.

D'Orbigny, A.D. 1826. Tableau methodique de la classe des Cephalapodes. Annales des Sciences Naturelles 7 (1): 96-314.

De la Harpe, P. 1880. Note Sur les Nummulites partschi et costeri, de la Harpe, du calcaire du Michelsberg, pres Stockerau (Autriche) et du Gurnigelsandstein de Suisse. Bulletin de la Societe Vaudoise des Sciences Naturelles 17 (84): 33-40.

Di Carlo, M., G. Acoordi, F. Carbone, and J. Pignatti. 2010. Biostratigraphic analysis of Paleogene lowstand wedge conglomerates of a tectonically active platform margin (Zakynthos Island, Greece). Journal of Mediterranean Earth Sciences 2: 31-92.

Dinçer, F., and N. Avşar. 2004. Benthic foraminiferal biostratigraphy of the tertiary (Lutetian) sediments of the Çamardı (Niğde). Bulletin for Earth Sciences Application and Research Centre of Hacettepe University 30: $35-48$.

Drobne, K. 1977. Alveolines paleogenes de la Slovenie et de I'Istrie. Schweizerische Paläontologische Abhandlungen 99: 1-132. 
Drobne, K., V. Cosovic, A. Moro, and D. Buckovic. 2011. The role of the Paleogene Adriatic carbonate platform in the spatial distribution of Alveolinids. Turkish Journal of Earth Sciences 20: 721-751.

Drobne, K., R. Pavlovec, and F. Drobne. 1977. Paleogene larger foraminifera from the area between Mezica and Slovenj grade (NW Yogoslavia). Razprave IV Razreda SAZU 20: 1-88.

Foster, L.C., D.N. Schmidt, E. Thomas, S. Arndt, and A. Ridgwell. 2013. Surviving rapid climate change in the deep sea during the Paleogene hyperthermals. Proceedings of the National Academy of Sciences 110 (23): 9273-9276.

Fricke, H.C., and S.L. Wing. 2004. Oxygen isotope and paleobotanical estimates of temperature and $\delta^{18} \mathrm{O}$-latitude gradients over North America during the early Eocene. American Journal of Science 304: 612-635.

Görür, N., and O. Tüysüz. 2001. Cretaceous to Miocene palaeogeographic evolution of Turkey: Implications for hydrocarbon potential. Journal of Petroleum Geology 24 (2): 119-146.

Higgins, J.A., and D.P. Schrag. 2006. Beyond methane: Towards a theory for the Paleocene-Eocene thermal maximum. Earth and Planetary Science Letters 245 (3-4): 523-537.

Hottinger, L. 1960. Researches Sur les Alveoles du Paleocene et de I'Eocene. Mémoires Suisses de Paleontologie 75/76: 24318 pls., 117 figs.

Inan, N., and S. Inan. 1999. New findings on the age and depositional conditions from the Tokuş formation (Sivas, Türkiye). Bulletin of the Geological Society of Turkey 42 (1): 119-130.

Karabaşoğlu, A., N. Özgen-Erdem, and M. Akyazı. 2002. Foraminiferal biostratigraphy of Paleocene/Eocene units outcropping in south of Eskişehir, 141-142. Ankara: 55th Geological Congress of Turkey, Abstract Book.

Kaya, O., and A. Dizer. 1982. Stratigraphy and structure of upper cretaceous and Paleogene rocks in north of Bolu. Mineral Research and Exploration Bulletin 97 (98): 57-77.

Keskin, I. 2017. Tarihi Safranbolu'yu çevreleyen kaya şevlerindeki duraysızlık problemlerinin kinematik analizlerle değerlendirilmesi. Sakarya University, Journal of Science 21 (5): 769-781.

Koçyiğit, A. 1987. Stratigraphy and nature of the northern margin of the Karabük-Safranbolu Tertiary Basin. Bulletin of the Geological Society of Turkey 30: 61-69.

Lowenstein, T.K., and R.V. Demicco. 2006. Elevated Eocene atmospheric $\mathrm{CO}_{2}$ and its subsequent decline. Science 313: 1928.

Moix, P., L. Beccaletto, H.W. Kozur, C. Hochard, F. Rosselet, and G.M. Stampfli. 2008. A new classification of the Turkish terranes and sutures and its implication for the paleotectonic history of the region. Tectonophysics 451: 7-39.

Molina, E., E. Angori, A. Arenillas, H. Brinkhuis, E.M. Crouch, H. Luterbacher, S. Monechi, and B. Schmitz. 2003. Correlation between the Paleocene/ Eocene boundary and the Ilerdian at campo, Spain. Revue de Micropaleontologie 46: 95-109.

Nicolo, M.J., G.R. Dickens, C.J. Hollis, and J.C. Zachos. 2007. Multiple early Eocene hyperthermal: Their sedimantary expression on the New Zealand continental margin and in the deep sea. Geological Society of America 35 (8): 699-702.

Okay, A.I. 2008. Geology of Turkey: A synopsis. Anschnitt 21: 19-42.

Önoğlu, N. 2000. Early Eocene nummulid and alveolins of Western Anatolia, 270-272. 53th Geological Congress of Turkey Abstract Book, Chamber of Geological Engineers Publication, Ankara.

Özcan, E., G. Less, and B. Kertes. 2007. Late Ypresian to middle Lutetian orthophragminid record from central and northern Turkey: Taxonomy and remarks on zonal scheme. Turkish Journal of Earth Sciences 16: 281-318.

Özce, F.S., E. Serttaş, M. Sürmeli, S. Eğdemir, and N. Özgen-Erdem. 2013. Benthic foraminifera biostratigraphy of the lower-middle Eocene deposits in the Ağcakışla area (Sivas-Sarkışla). Bulletin of the Geological Society of Turkey 56 (3): 189-202.

Özgen, N. 1998. Paleocene-Eocene benthic foraminifera assemblages in the Western Pontids. Bulletin of the Geological Society of Turkey 41: 263-278.

Özgen-Erdem, N. 2002. Sirelella safranboluensis n. gen., n.sp., a foraminifer from the Lutetian of the Safranbolu area (northern Turkey). Micropaleontology 48 (1): 79-86.
Özgen-Erdem, N. 2008. Biostratigraphy of Thanetian-llerdian benthic foraminifera in the Akçataş-Cebeci (NW Tosya - SE Kastamonu) region. Mineral Research and Exploration Bulletin 137: 49-59.

Özgen-Erdem, N., M. Akyazı, and A. Karabaşoğlu. 2007. Biostratigraphic interpretation and systematic of Alveolina assemblages from the Ilerdian-Cuisian limestones of southern Eskişehir, Central Turkey. Journal of Asian Earth Sciences 29: 911-927.

Özgen-Erdem, N., N. Inan, M. Akyazı, and C. Tunoğlu. 2005. Benthonic foraminiferal assemblages and microfacies analysis of PaleoceneEocene carbonate rocks in the Kastamonu region, northern Turkey. Journal of Asian Earth Sciences 25 (3): 403-417.

Öztürk, A., S. İnan, and S.Z. Tutkun. 1984. Stratigraphy of Abant-Yeniçăg (Bolu) region. Cumhurivet University, Journal of the Faculty of Engineering, Serial A 1: 1-148.

Rea, D.K., J.C. Zachos, R.M. Owen, and P.D. Gingerich. 1990. Global change at the Paleocene-Eocene boundary: Climatic and evolutionary consequences of tectonic events. Palaeogeography, Palaeoclimatology, Palaeoecology 79: 117-128.

Saner, S. 1980. Explanation of the development of the Western Pontid mountains and adjacent basins, based on plate tectonic theory, northwestern Turkey. Mineral Research and Exploration Bulletin 93 (94): 1-19.

Saner, S., I. Taner, Z. Aksoy, M. Siyako, and K.A. Burkan. 1980. Geological structure of Safranbolu Basin and tertiary paleogeography, 111-122. Ankara: Proceedings of the 5th Turkey Petroleum Congress, Turkish Petroleum Company.

Serra-Kiel, J., L. Hottinger, E. Caus, K. Drobne, C. Ferrandez, A.K. Jauhri, G. Less, R. Pavlovec, J. Pignatti, J.M. Samso, H. Schaub, E. Sirel, A. Strougo, Y. Tambareau, J. Tosquella, and E. Zakrevskaya. 1998. Larger foraminiferal biostratigraphy of the Tethyan Paleocene and Eocene. Bulletin de la Société Geéologique de France 169: 281-299.

Sexton, P.F., R.D. Norris, P.A. Wilson, H. Pälike, T. Westerhold, U. Röhl, C.T. Bolton, and S. Gibbs. 2011. Eocene global warming events driven by ventilation of oceanic dissolved organic carbon. Nature 471: 349-352.

Sezen, E.T. 1983. Geological investigation of Pazarköy (Bolu NE) region. MSC thesis. Ankara: Geological Engineering Departmant, Hacettepe University.

Sirel, E. 1975. Stratigraphy of south of Polatlı (SW Ankara). Bulletin of the Geological Society of Turkey 19: 89-102.

Sirel, E. 1976. Description of six new species of the Alveolina found in the south of Polatlı (SW Ankara) region. Bulletin of the Geological Society of Turkey 19: 19-22.

Sirel, E. 1992. Field trip. In Introduction to the Early Paleogene of the Haymana-Polatlı Basin. IGCP 286 'Early Paleogene Benthos' - Third Meeting Ankara (Turkey). General Directorate of Mineral Research and Exploration, 1-10.

Sirel, E. 1998. Foraminiferal description and biostratigraphy of the Paleocene-lower Eocene shallow-water limestones and discussions on the cretaceous-tertiary boundary in Turkey. General Directorate of the Mineral Research and Exploration, Monography Series 2: 1-117.

Sirel, E. 2000. Biostratigraphy of the middle/ upper Eocene/ Oligocene boundaries at the eastern Turkey. Annali del Museo Civico di Storia Ferrara 3: 61-70.

Sirel, E., and S. Acar. 2008. Description and biostratigraphy of the ThanetianBartonian Glomalveolinids and Alveolinds of Turkey. Chamber of Geological Engineering Publication, Ankara, Special Volume 2: 1-265.

Sirel, E., and H. Gündüz. 1976. Description and stratigraphical distribution of the some species of the genera Nummulites, Assilina and Alveolina from the llerdian, Cuisian and Lutetian of Haymana region (Sankara). Bulletin of the Geological Society of Turkey 19 (1): 31-44.

Španiček, J., V. Ćosović, E. Mrinjek, and I. Vlahović. 2017. Early Eocene evolution of carbonate depositional environments recorded in the Čikola canyon (north Dalmatian Foreland Basin, Croatia). Geologia Croatica 70 (1): 11-25.

Timur, E., and A. Aksay. 2002. 1:100 000 scale geological map of Turkey, no.:30 Zonguldak-F 29 sheet. Ankara: Geological studies department.

Tosquella, J., J.M. Samso, and J. Serra-Kiel. 1990. The genera Alveolina and Nummulites (macroforaminifera) in the Ilerdian to mid-Cuisian in the Graus Basin, Huesca. II. Nummulites systematics. Bolatín Geológico y Minero 101 (3): 351-403. 
Uysal, H. 1959. Geology and lignite deposits of Bolu-Merkeşler region. Mineral Research and Exploration Bulletin 52: 107-115.

Yılmaz, Y., O. Tüysüz, E. Yigitbaş, S.C. Genç, and A.M.C. Şengör. 1997. Geology and tectonic evolution of the Pontides. In Regional and petroleum geology of the Black Sea and surrounding region, American Association of Petroleum Geologists, memoir, ed. A.G. Robinson, vol. 68, 183-226.

\section{Publisher's Note}

Springer Nature remains neutral with regard to jurisdictional claims in published maps and institutional affiliations.

\section{Submit your manuscript to a SpringerOpen ${ }^{\circ}$ journal and benefit from:}

- Convenient online submission

- Rigorous peer review

- Open access: articles freely available online

- High visibility within the field

- Retaining the copyright to your article

Submit your next manuscript at $\boldsymbol{\wedge}$ springeropen.com 